\title{
Value-Added Bio-Chemicals Commodities from Catalytic Conversion of Biomass Derived Furan-Compounds
}

\author{
Aitziber Iriondo * ${ }^{\infty}$, Ion Agirre ${ }^{\circledR}$, Nerea Viar ${ }^{\circledR}$ and Jesús Requies \\ Faculty of Engineering, University of the Basque Country (UPV/EHU), Plaza Ingeniero Torres Quevedo 1, \\ 48013 Bilbao, Spain; ion.agirre@ehu.eus (I.A.); nerea.viar@ehu.eus (N.V.); jesus.requies@ehu.eus (J.R.) \\ * Correspondence: aitziber.iriondo@ehu.eus
}

Received: 15 July 2020; Accepted: 6 August 2020; Published: 7 August 2020

\begin{abstract}
The depletion of fossil resources in the near future and the need to decrease greenhouse gas emissions lead to the investigation of using alternative renewable resources as raw materials. One of the most promising options is the conversion of lignocellulosic biomass (like forestry residues) into bioenergy, biofuels and biochemicals. Among these products, the production of intermediate biochemicals has become an important goal since the petrochemical industry needs to find sustainable alternatives. In this way, the chemical industry competitiveness could be improved as bioproducts have a great potential market. Thus, the main objective of this review is to describe the production processes under study (reaction conditions, type of catalysts, solvents, etc.) of some promising intermediate biochemicals, such as; alcohols (1,2,6-hexanetriol, 1,6-hexanetriol and pentanediols (1,2 and 1,5-pentanediol)), maleic anhydride and 5-alkoxymethylfuran. These compounds can be produced using 5-hydroxymethylfurfural and/or furfural, which they both are considered one of the main biomass derived building blocks.
\end{abstract}

Keywords: biomass; 5-hydroxymethylfurfural; furfural; catalytic conversion; biochemical; alcohols; alkoxymethylfurans; maleic anhydride

\section{Introduction}

The world energy consumption has incremented up to $16 \%$ over the last 10 years (2007-2017) [1] (see Figure 1). This raise can be attributed to economic trends (the development of the global economy) and demographic changes (the growth of the population) [1-4].

Oil, coal and natural gas are currently the world's main non-renewable resources for producing energy. In 2017, the most consumed resource was oil (34\%), followed by coal (28\%) and natural gas $(23 \%)$. The total of these non-renewable supplies rises to $85 \%$ of the total world energy consumption [1]. These data are summarized in Figure 2.

The concern about climate change and the depletion of fossil fuels have led to investigate new renewable and green producing energy systems. The lignocellulosic biomass is one of the promising renewable sources to produce value added chemicals because of its renewability, abundance and wide distribution in nature [2,5]. It is mainly composed by three polymers: cellulose, hemicellulose and lignin [5-7]. These components can be separated to treat them independently [8]. Different pretreatments are used for this purpose: physical (reducing the particle size by mechanical force or heat), chemical (using ionic liquids or other reagents to dissociate biomass) and biological (favoring the biomass digestion by microbes or fungal enzymes) [5] 


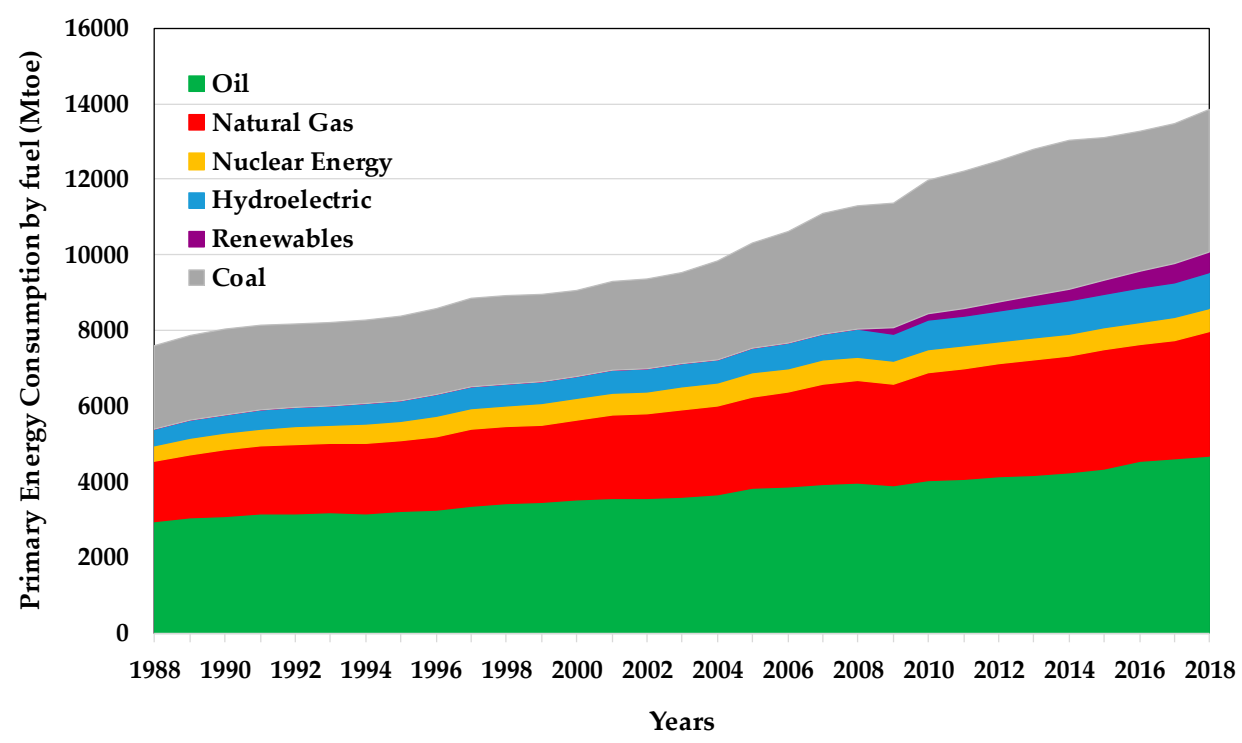

Figure 1. World energy consumption [1].

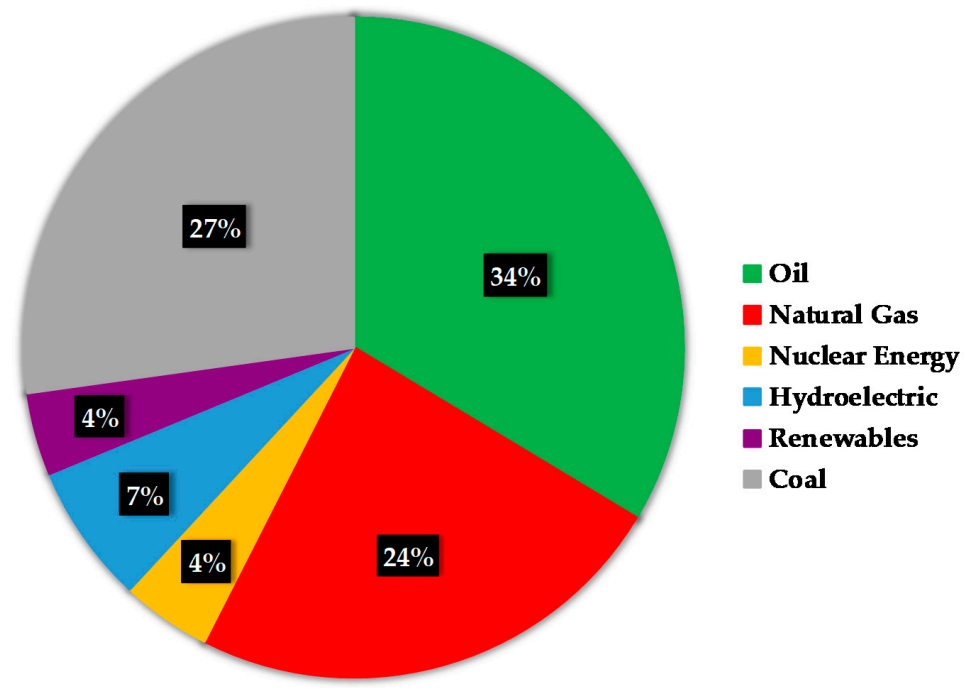

Figure 2. World energy consumption 2017 (data obtained from [1]).

Cellulose is the largest fraction of lignocellulosic biomass, constituting $30-50 \%$ by weight [7]. It is a linear polymer of hexoses $[6,9]$. Glucose $\left(C_{6}\right.$ sugar $)$ can be dehydrated into 5 -hydroxymethylfuran (HMF; see Figure 3) [10,11].

Hemicellulose is the second most abundant polysaccharide found in lignocellulosic biomass (15-30\% by weight) [5,9]. It can be hydrolyzed into monosaccharides (primarily xylose). Then, this five-carbon sugar is dehydrated to produce furfural (FF; see Figure 3) $[2,5,6,8,12,13]$. It has been industrially produced since $1921-1922[2,6,8,12]$ and this process is still currently in use $[14,15]$. FF is currently commercially produced by acidic-catalytic transformation of biomass derived $C_{5}$ sugars $[2,6]$. The achieved yield does not exceed $50 \%$, due to undesired side reactions. This drawback needs to be overcome by the development of inexpensive and environmentally friendly technologies to produce FF from renewable feedstock $[2,6,15]$. 


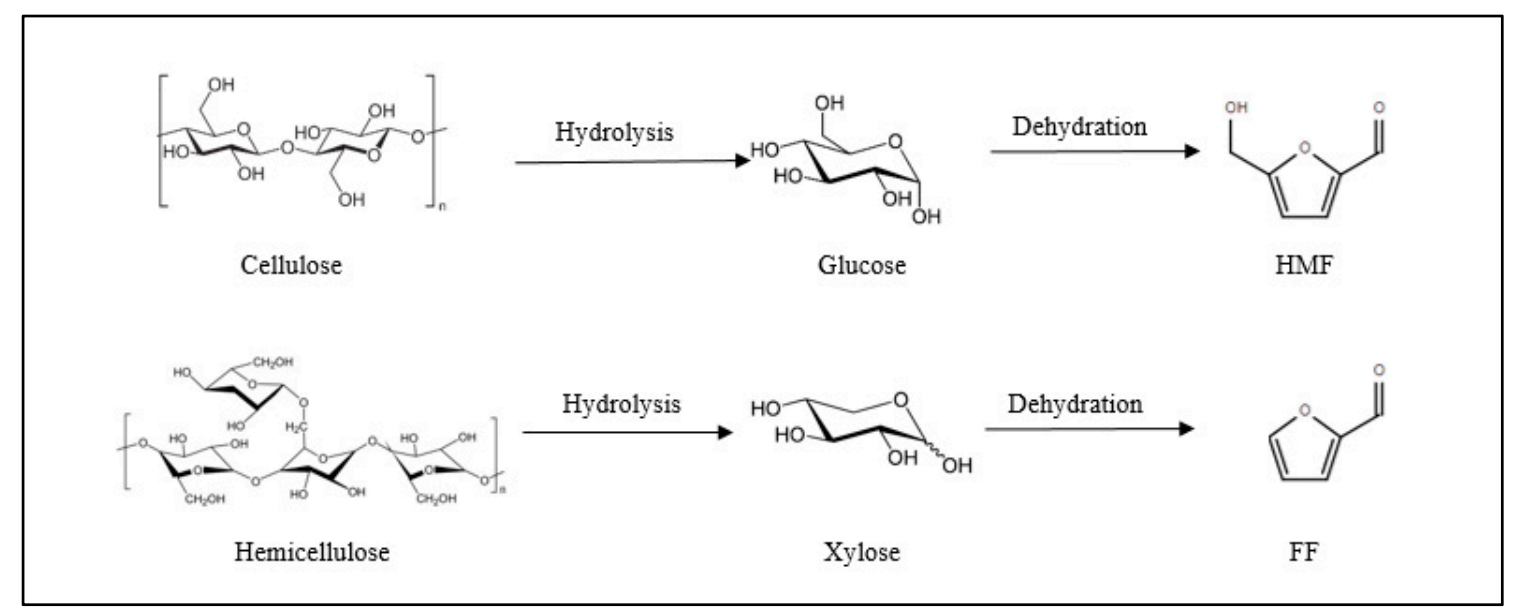

Figure 3. Reaction pathway to produce FF and HMF from lignocellulosic biomass (adapted from [16]).

New research is focused on the investigation of new catalytic systems to produce FF from hemicellulose. Both homogeneous and heterogeneous catalysts are being studied. Organic acids such as oxalic acid, levulinic acid or maleic acid and mineral acids such as $\mathrm{H}_{2} \mathrm{SO}_{4}, \mathrm{HCl}$ or $\mathrm{H}_{3} \mathrm{PO}_{4}$ can be used as homogeneous catalysts. Heterogeneous catalysts incorporate solid catalysts $\left(\mathrm{TiO}_{2}, \mathrm{ZrO}_{2}\right.$ and zeolites) and Lewis acids $\left(\mathrm{CrCl}_{3}, \mathrm{ZnCl}_{2}\right.$ and $\left.\mathrm{AlCl}_{3}\right)[16,17]$. Many investigations are also focused on the utilization of a proper solvent. Organic solvents, such as dimethyl sulfoxide (DMSO), $\gamma$-valerolactone (GVL) and ionic liquids (e.g., liquid salts) and biphasic aqueous/organic systems, such as water/toluene or water/methyl isobutyl ketone (MIBK), have been proposed as the most efficient ones for achieving high yields of FF [5,12]. FF has many applications; it can be used as an extracting agent on the refinery process of oil and diesel, as an additive in many products such as flavoring agents, insecticides, etc. Moreover, it can be further converted into a wide range of value added chemicals $[5,7,8,12,14]$.

HMF produced from the hexose dehydration has been investigated for over 100 years [18]. Different catalytic systems have been reported obtaining high yields of HMF. These systems use both heterogeneous and homogeneous catalysts such as mineral and organic acids, salts and zeolites (similar to the FF production) $[16,19,20]$. Diverse solvents have been studied for the production of HMF, including ionic liquids, organic solvents (DMSO, acetone and tetrahydrofuran (THF)) and biphasic aqueous/organic systems (e.g., water/toluene) $[16,19,20]$.

At present, the cost of HMF is three orders of magnitude higher than fossil-based chemicals (around 500-1500 USD/kg) [21]. Therefore, the market for HMF is limited if it is compared to the market of the final products that can be obtained from this platform molecule [11]. These chemicals derived from the hydrogenation or oxidation of HMF can be used in pharmaceuticals, polymers, resins, solvents, fungicides and biofuels [11,20].

HMF and FF have been included in the top 10 value-added chemicals derived from biomass for suitable production of fuels and chemicals $[2,12,13]$. These chemicals have been widely studied for the production of biofuels. Bozell et al. [13] reveal that the return on investment in biofuel-only operations does not overcome the economical goal due to the low value of fuels. Moreover, these processes involve high hydrogen consumption [22]. Biorefinery needs to integrate biofuels with high value-added biobased chemicals to achieve simultaneously the economical and energetic (replacement of petroleum with green and renewable raw materials) goals [13]. In this sense, value added chemicals such as sugar alcohols, maleic anhydride (MAN) or alkoxymethylfurfural (AMF) compounds are interesting products that can be obtained from HMF or FF.

New research reported in the literature is based on the ring-opening of HMF and FF to produce aliphatic or linear polyols (sugar alcohols) [23-25] for the chemical industry [26] by means of hydrogenation processes. Among these products, whose general formula is $\mathrm{C}_{n} \mathrm{H}_{2 n+2} \mathrm{O}_{n}$, the most investigated alcohols are diols and triols. These kinds of alcohols are useful as polymeric monomers, 
especially diols, to produce polyester and polyurethanes, with a variety of applications such as resins, coatings, plasticizers and adhesives [23-25]. Moreover, these chemical commodities can also be used as: i) ingredients in the field of cosmetics and medicaments as humectants, solvents and viscosity-controlling agents, ii) components in printing inks, disinfectants and surfactants and iii) in the case of triols, as precursors of their diol counterparts [23,27].

Another high value chemical is MAN, which is used in numerous applications currently in the chemical industry (resins, agrochemicals, pharmaceuticals, etc.) and has an annual consumption of more than $1600 \mathrm{Kt}$ [28-30]. Two principal feedstocks are currently used for its industrial production, benzene and n-butane, which can be substituted by the aforementioned two platform molecules [31-33].

Another important reaction is the etherification of HMF to produce AMF compounds. These compounds are mainly used as biodiesel additives. Among these biofuels 5-ethoxymethylfurfural (EMF) is considered to be a promising liquid biofuel due to its high energy density [34-37]. 5,5-oxy-bismethylene-2-furaldehyde (OBMF) can be used for the imine-based polymers preparation [38] and for the production of heterocyclic ligands and hepatitis antivirals [39]. Furthermore, some of these AMF can be used as precursors of other important compounds such as 2,5-furandicarboxylic acid (FDCA) [40]. Many chemical/biochemical companies including DuPont, Corbion and Synvina (a BASF-Avantium joint venture) have developed an efficient synthesis of FDCA.

Currently, these compounds are produced from the petroleum-derived chemicals through different and complex reactions $[23,27,37,40]$. However, as it is discussed in the following sections, they can be obtained from biomass-derived furan-compounds, providing simplicity to the production process and sustainability to these chemical commodities' applications [27,37,41].

Therefore, the main objective of this review is the identification of the main catalytic processes related to the production of sugar alcohols, maleic anhydride (MAN) or alkoxymethylfurfural (AMF), analyzing and discussing the best results obtained in terms of operating conditions, temperature, pressure, solvents to be used, catalysts used, reaction equipment, etc., using as a raw material the compounds derived from biomass such as furfural and 5-hydroxymethylfurfural.

\section{Polyols}

\subsection{1,2,6-Hexanetriol (HT) Production through Catalytic Conversion of HMF}

The formation of 1,2,6-hexanetriol (HT) leads to one-spot or sequential liquid phase [25-27,41,42] hydrogenation and ring-opening reactions via hydrogenolysis using mainly batch reactors $[26,27,41,42]$. Considering this, $\mathrm{C}=\mathrm{O}, \mathrm{C}=\mathrm{C}$ and $\mathrm{C}-\mathrm{O}$ (belonging to furan-ring) bonds cleavage is desirable for the HT production. The rate of these bonds cleavage should be appropriate to avoid the formation of low carbon content oxygenates and alkanes [43]. Based on this, the most reported reaction mechanisms for HMF conversion into HT are reflected in Figure 4; DHMF (2,5-dihydroxymethylfuran), DHMTHF (2,5-dihydroxymethyltetrahydrofuran), HD (1,6-hexanediol), 1,5-HD (1,5-hexanediol) and 1,2-HD (1,2-hexanediol) could appear as possible intermediate and degradation products. 


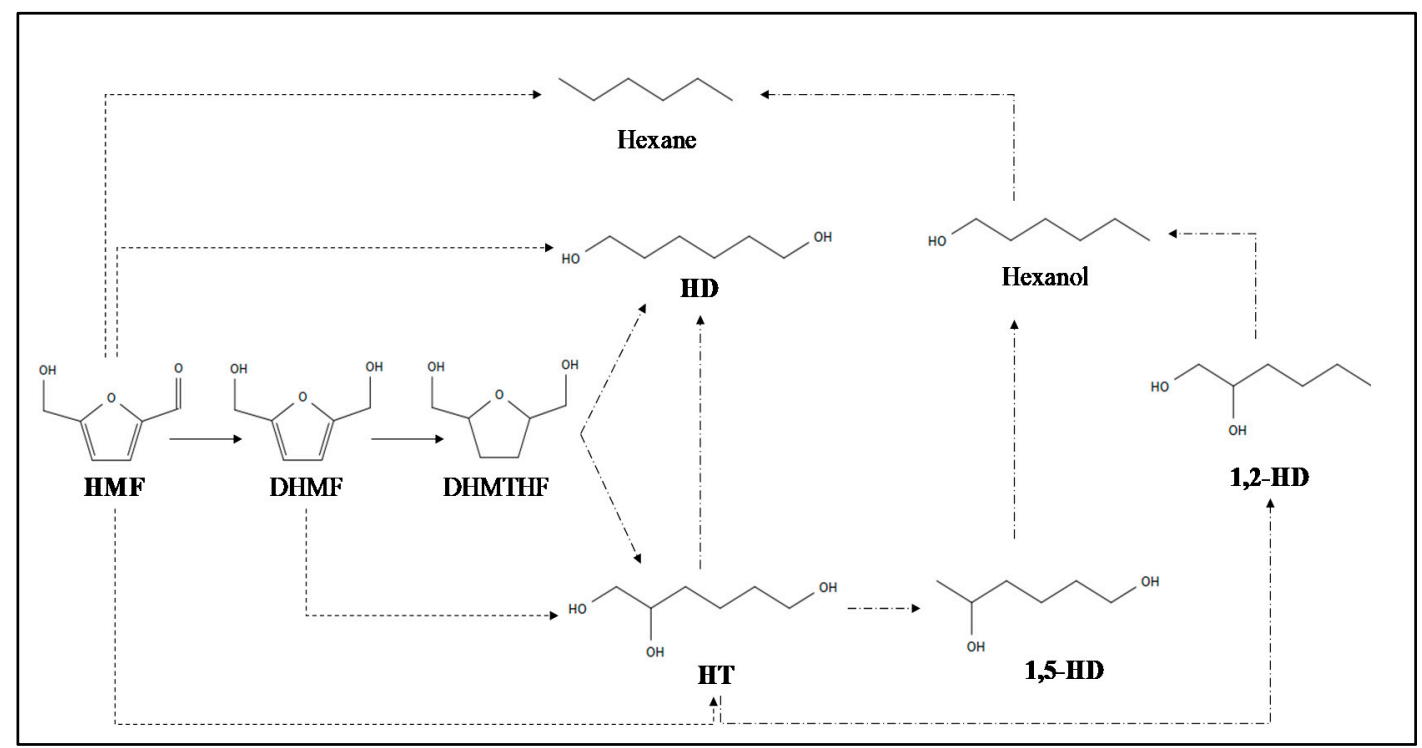

Figure 4. Possible reaction routes and side reactions (solid arrow: hydrogenation; dot arrow: hydrogenation/hydrogenolysis and dash-dot arrow: hydrogenolysis) for HT production adapted from $[23,24,26,27,42,44,45]$.

Generally, cracking and hydrogenation reactions take place in acid and metal sites of the employed heterogeneous catalytic systems, respectively $[25,43,46,47]$. Therefore, the transformation of HMF into HT requires bifunctional catalysts [25,47]. Yao et al. [27] studied a direct production of HT from HMF using coprecipitated $\mathrm{Ni}-\mathrm{CoAl}$ mixed oxides, with different metal contents, as well as Raney $\mathrm{Ni}$ and Raney Co type alloy catalysts. It is well known that $\mathrm{Ni}$ is active in hydrogenation reactions [25] and, the addition of a second metal can result in the formation of an alloy with a synergetic effect, improving the catalytic activity and the selectivities [27] to the desired products. Moreover, the presence of metal oxides with acid-basic properties has a significant role in the reaction mechanism. In this sense, the acid metal oxides seem to be selective to furan ring-opening, increasing the polyols formation [48]. Although all of the tested catalysts presented almost a complete HMF conversion, not all were active in the furan ring-opening.

As it can be observed in Table 1, only catalysts designed as $0.3 \mathrm{Ni} 2.7 \mathrm{CoAl}, 0.5 \mathrm{Ni} 2.5 \mathrm{CoAl}$ and $0.9 \mathrm{Ni2} .1 \mathrm{CoAl}$ were able to produce a significant amount of HT, mainly via DHMF intermediate formation, reaching the highest yield of $37.4 \%$, for the $0.5 \mathrm{Ni} 2.5 \mathrm{CoAl}$ catalyst at $120{ }^{\circ} \mathrm{C}, 4 \mathrm{MPa}$ of $\mathrm{H}_{2}$ and $4 \mathrm{~h}$. The good performance of this catalyst was due to the appropriate Ni/Co ratio, which provided enough $\mathrm{Ni}-\mathrm{CoO}$ active sites and $\mathrm{Ni}^{0}$ species to produce ring-opening and hydrogenation. The temperature and pressure increase had a negative influence in HT formation, resulting in degradation and polymerization reactions. However, the increase of time on the reaction up to $12 \mathrm{~h}$ improved the HT yield, reaching a value of $64.5 \%$.

Buntara et al. [26] also worked in the HT formation using DHMTHF as a raw material. The tested catalysts were mainly supported bimetallic catalysts containing hydrogenating ( $\mathrm{Rh}, \mathrm{Pd}$ and $\mathrm{Pt}$ ) and oxidic promoters $\left(\mathrm{Re}^{7+}, \mathrm{Mo}^{6+}, \mathrm{W}^{6+}, \mathrm{Cr}^{3+}, \mathrm{Mn}^{2+}\right.$ and $\left.\mathrm{Sn}^{2+}\right)$ metals. Apart from $\gamma-\mathrm{Al}_{2} \mathrm{O}_{3}$, other types of supports, like $\mathrm{SiO}_{2}, \mathrm{SiO}_{2}-\mathrm{Al}_{2} \mathrm{O}_{3}, \mathrm{CeO}_{2}, \mathrm{TiO}_{2}$, carbon, $\mathrm{Nb}_{2} \mathrm{O}_{5}$ and sulphated- $\mathrm{ZrO}_{2}$ were tested. According to the results, after the reduction treatment, the amorphous $\mathrm{SiO}_{2}$ (Fuji G6-3)-supported $\mathrm{Rh}-\mathrm{ReO}_{\mathrm{x}}$ catalyst with the $\mathrm{Rh} / \mathrm{Re}$ molar ratio of 0.5 , followed by $\mathrm{Rh}-\mathrm{ReO}_{\mathrm{x}} / \mathrm{SiO}_{2}$ (HDK-T40) and $\mathrm{Rh}-\mathrm{ReO}_{\mathrm{x}} / \mathrm{Nb}_{2} \mathrm{O}_{5}$, showed the best activity and selectivity toward HT formation, resulting in $31 \%$ of the conversion and $84 \%$ of selectivity at $120^{\circ} \mathrm{C}, 8 \mathrm{MPa}$ of $\mathrm{H}_{2}$ and $4 \mathrm{~h}$. The same catalyst synthetized via $\mathrm{Rh}$ nitrate precursor presented lower conversion, $24 \%$, and a similar selectivity. In the same line as Yao et al. [27], Buntara et al. [26] associated the good performance of the $\mathrm{Rh}-\mathrm{ReO}_{\mathrm{x}} / \mathrm{SiO}_{2}$ catalyst, prepared using $\mathrm{Rh}$ chloride, to the presence of Rh-Re alloys with large particles size generated using mild reduction pretreatment conditions $\left(120^{\circ} \mathrm{C}, 1 \mathrm{MPa}\right.$ of $\mathrm{H}_{2}$ and $\left.1 \mathrm{~h}\right)$. Catalysts containing Re combined 
with noble Pt and Pd showed negligible conversion and selectivities probably due to the use of inadequate metal precursors or low amounts of bimetallic alloys. Chen et al. [49], as Buntara et al. [26], concluded that Ru catalysts were more selective toward HT than Pt and Pd catalysts, due to their capacity for DHMF hydrogenation and DHMTHF hydrogenolysis having a total conversion of HMF. On the other hand, Buntara et al. [26] established that temperature and time have a negative influence on the catalysts activity and selectivity, as it can be observed in Table 1. In this sense, some authors [44] also reported that a temperature and time increase improves DHMTHF conversion but reduces HT selectivity due to the formation of HT degradation products, such as diols and mono-alcohols, which are discussed in Section 2.2. When $\mathrm{WO}_{\mathrm{x}}$ is used instead of $\mathrm{ReO}_{\mathrm{x}}$ in the catalyst, the combination with Pt type metal provided a HT selectivity above $95 \%$ with a DHMTHF conversion around $23 \%$, being the reaction conditions $160^{\circ} \mathrm{C}$ and $5.5 \mathrm{MPa}$ of $\mathrm{H}_{2}[41,50]$.

Table 1. Different metal catalysts used for HT production with summary of reaction conditions and catalytic activity.

\begin{tabular}{|c|c|c|c|c|c|c|c|c|c|}
\hline Catalyst & $\mathrm{T}\left({ }^{\circ} \mathrm{C}\right)$ & P (MPa) & Time (h) & Solvent & $\begin{array}{c}\text { Raw } \\
\text { Material }\end{array}$ & $\begin{array}{c}\text { Target } \\
\text { Product } \\
\text { (TP) }\end{array}$ & $\chi(\%)$ & $\begin{array}{l}\mathrm{S}_{\mathrm{TP}} \\
(\%)\end{array}$ & Ref. \\
\hline $0.3 \mathrm{Ni} 2.7 \mathrm{CoAl}$ & \multirow{6}{*}{120} & \multirow{5}{*}{4} & & \multirow{7}{*}{$\mathrm{MeOH}$} & \multirow{7}{*}{ HMF } & \multirow{7}{*}{ HT } & \multirow{7}{*}{100} & $14.8^{\mathrm{y}}$ & \multirow{7}{*}{ [27] } \\
\hline $0.5 \mathrm{Ni} 2.5 \mathrm{CoAl}$ & & & 4 & & & & & $37.4^{y}$ & \\
\hline $0.9 \mathrm{Ni} 2.1 \mathrm{CoAl}$ & & & & & & & & $23.3^{y}$ & \\
\hline $0.5 \mathrm{Ni2} .5 \mathrm{CoAl}$ & & & 8 & & & & & $54.4^{\mathrm{y}}$ & \\
\hline $0.5 \mathrm{Ni} 2.5 \mathrm{CoAl}$ & & & 12 & & & & & $64.5^{\mathrm{y}}$ & \\
\hline $0.5 \mathrm{Ni} 2.5 \mathrm{CoAl}$ & & 6 & \multirow{2}{*}{8} & & & & & $\approx 42.5^{\mathrm{y}}$ & \\
\hline $0.5 \mathrm{Ni} 2.5 \mathrm{CoAl}$ & 140 & 4 & & & & & & $41.9^{y}$ & \\
\hline $\mathrm{Rh}-\mathrm{ReO}_{\mathrm{x}} / \mathrm{SiO}_{2}{ }^{\mathrm{a}}$ & \multirow{7}{*}{120} & \multirow{8}{*}{8} & \multirow{6}{*}{4} & \multirow{8}{*}{$\mathrm{H}_{2} \mathrm{O}$} & \multirow{8}{*}{ DHMTHF } & \multirow{8}{*}{ HT } & 31 & 84 & \multirow{8}{*}{ [26] } \\
\hline $\mathrm{Rh}^{\mathrm{b}}-\mathrm{ReO}_{\mathrm{x}} / \mathrm{SiO}_{2}{ }^{\mathrm{a}}$ & & & & & & & 24 & 84 & \\
\hline $\mathrm{Rh}-\mathrm{ReO}_{\mathrm{x}} / \mathrm{SiO}_{2}{ }^{2}$ & & & & & & & 14 & 85 & \\
\hline $\mathrm{Rh}-\mathrm{ReO}_{\mathrm{x}} / \mathrm{Nb}_{2} \mathrm{O}_{5}$ & & & & & & & 17 & 95 & \\
\hline $\mathrm{Rh}-\mathrm{Pt} / \mathrm{SiO}_{2}$ a & & & & & & & 1 & 0 & \\
\hline $\mathrm{Rh}-\mathrm{Pd} / \mathrm{SiO}_{2}{ }^{\text {a }}$ & & & & & & & 1 & 0 & \\
\hline $\mathrm{Rh}-\mathrm{ReO}_{\mathrm{x}} / \mathrm{SiO}_{2}{ }^{\mathrm{a}}$ & & & \multirow{2}{*}{20} & & & & 53 & 76 & \\
\hline $\mathrm{Rh}-\mathrm{ReO} \mathrm{O}_{\mathrm{x}} / \mathrm{SiO}_{2}{ }^{\mathrm{a}}$ & 180 & & & & & & 88 & 34 & \\
\hline $\mathrm{Pt}-\mathrm{WO}_{\mathrm{x}} / \mathrm{TiO}_{2}$ & 160 & 5.5 & 8 & $\mathrm{H}_{2} \mathrm{O}$ & DHMTHF & HT & 23 & 95 & [41] \\
\hline Unsupported Ru & \multirow{9}{*}{130} & \multirow{9}{*}{3} & 1 & & \multirow{9}{*}{ HMF } & \multirow{9}{*}{ DHMTHF } & 100 & $53\left(41^{e}\right)$ & \multirow{9}{*}{ [42] } \\
\hline Unsupported Ru & & & 2 & & & & 100 & $46\left(37^{e}\right)$ & \\
\hline $\mathrm{Ru} / \mathrm{C}$ & & & 2 & & & & 100 & $56\left(38^{e}\right)$ & \\
\hline $\mathrm{Ru} / \mathrm{CeO}_{2}$ & & & 6 & $\mathrm{H}_{2} \mathrm{O} /$ & & & 100 & $48\left(15^{\mathrm{e}}\right)$ & \\
\hline $\mathrm{Ru} / \mathrm{MgO}-\mathrm{ZrO}_{2}$ & & & 20 & 1-BuOH & & & 100 & $88\left(3^{\mathrm{e}}\right)$ & \\
\hline $\mathrm{Ru} / \gamma-\mathrm{Al}_{2} \mathrm{O}_{3}$ & & & 12 & & & & 100 & $89\left(10^{\mathrm{e}}\right)$ & \\
\hline Unsupported $\mathrm{Ru}{ }^{\mathrm{d}}$ & & & n.a. & & & & 100 & $75\left(12^{\mathrm{e}}\right)$ & \\
\hline Unsupported Ru & & & 2 & $\mathrm{H}_{2} \mathrm{O}$ & & & 100 & $22\left(50^{\mathrm{e}}\right)$ & \\
\hline Unsupported Ru & & & 2 & $\mathrm{THF} / \mathrm{H}_{2} \mathrm{O}$ & & & 100 & $50\left(28^{e}\right)$ & \\
\hline
\end{tabular}

$\mathrm{T} \rightarrow$ temperature; $\mathrm{P} \rightarrow$ pressure; $\mathrm{MeOH} \rightarrow$ methanol; $\mathrm{BuOH} \rightarrow$ butanol; $\chi \rightarrow$ conversion; $\mathrm{S}_{\mathrm{TP}} \rightarrow$ selectivity od the target product; $\mathrm{y} \rightarrow$ yield; $\mathrm{a} \rightarrow$ Fuji G6-3 type $\mathrm{SiO}_{2} ; \mathrm{b} \rightarrow$ prepared via Rh chloride precursor; $\mathrm{c} \rightarrow \mathrm{HDK}-\mathrm{T} 40$ type $\mathrm{SiO}_{2} ; \mathrm{d} \rightarrow$ feed treated for acidic compounds elimination; $\mathrm{e} \rightarrow$ sum of HT, 1,2,5-HT and 1,2,5,6-hexanetetraol selectivities; n.a. $\rightarrow$ not available.

Similar catalytic systems were used by Alamillo et al. [42] to produce DHMTHF from HMF, detecting the presence of HT and 1,2,5-hexanetriol (1,2,5-HT), among others. Regarding 1,2,5-HT product, it seems to be mainly produced via hydrogenation of 1-hydroxyhexane-2,5-dione, which was generated by acid-catalyzed ring-opening of DHMF [48,51]. Concretely, they [42] prepared $\mathrm{Ru}$ catalysts supported on oxides with high $\left(\mathrm{CeO}_{2}, \mathrm{MgO}_{2}-\mathrm{ZrO}_{2}\right.$ and $\left.\gamma-\mathrm{Al}_{2} \mathrm{O}_{3}\right)$ and low $\left(\mathrm{SiO}_{2}\right)$ isoelectric point, non-oxides (Vulcan carbon) and unsupported $\mathrm{Ru}$. These catalysts presented good activity achieving almost a total conversion of HMF. However, among the mentioned catalysts, the unsupported ones showed better selectivity toward HT (13\%) and 1,2,5-HT (13\%) at $130{ }^{\circ} \mathrm{C}$ and $3 \mathrm{MPa}$ using a biphasic system of water/1-butanol. While the high isoelectric supported catalysts, which have mainly basic properties, provided higher DHMTHF selectivity $\left(91 \%\right.$ for $\mathrm{Ru} / \mathrm{CeO}_{2} ; 88 \%$ for $\mathrm{Ru} / \mathrm{MgO}-\mathrm{ZrO}_{2}$ and $89 \%$ for $\gamma-\mathrm{Al}_{2} \mathrm{O}_{3}$ ) in the detriment of hexanetriols selectivity (around $1 \%$ ) for the highest time of reaction (see Table 1). Hexanetriols selectivity is also influenced by acid impurities of the used feed, solvents and active metal. The presence of levulinic acid and formic acid, derived from 
HMF production via monosaccharides [16], favors the degradation reactions resulting in higher selectivity toward hexanetriols. The same phenomenon was observed when a single-phase system containing water was used. It seems that water is responsible of the additional degradation process. These researchers [42] concluded that Pd and Pt monometallic catalysts were less selective toward hexanetriols [26], but specially toward DHMTHF. The data reported by Kataoka et al. [52] also suggests the low capacity of Pt supported catalysts to transform HMF into $\mathrm{HT}$ at $135^{\circ} \mathrm{C}, 3 \mathrm{MPa}$ of $\mathrm{H}_{2}$ and $24 \mathrm{~h}$. However, among the tested catalysts, the ones supported in supports with a basic nature (hydrotalcite, $\mathrm{CeO}_{2}$ and $\mathrm{MgO}$ ) were more selective toward $\mathrm{HT}$ production than the ones supported in acidic or inert supports. Moreover, they reported that the promotion of $\mathrm{Pt} / \mathrm{CeO}_{2}$ catalysts with $\mathrm{CoO}_{\mathrm{x}}$ improved HT yield from $27 \%$ to $42 \%$, being this last data the same as the $\mathrm{Pt} /$ hydrotalcite catalyst obtained. The good performance of the supported Pt catalysts could be due to the presence of the metal-support interface. Concretely, in the case of Pt catalysts supported in basic nature supports, their better behavior is associated to monodentate alkoxide adsorption and the nature type of the supports.

1,2,5-pentanetriol (1,2,5-PT) can be obtained from hydrogenation/hydrogenolysis of FF following a similar synthesis method to HT [48]. However, the majority of the literature deals with diols production [25, 53,54] (see Section 2.2.2, Figure 5 mentions the formation of 1,2,5-PT as an intermediate product).

\subsection{Diols from HMF and FF Using Metal Catalysts}

Hydrogenation/hydrogenolysis reactions can also allow the direct or sequential production of hexanediols and pentanediols from HMF or FF, respectively, for which bifunctional solid catalysts are also the most investigated solid materials.

\subsubsection{HMF Transformation into 1,6-Hexanediol (HD)}

The production of HD can be carried out in fixed bed [45] or batch reactors [55] using supported metallic catalysts. Xiao et al. [45] prepared supported monometallic Pd, for the HMF-DMHTHF reaction, and bimetallic $\mathrm{M}$ (metal)- $\mathrm{ReO}_{\mathrm{x}}$ catalysts for the HMF-HD reaction (M one of the following metals: Ir, Pd, Pt, Rh, Pd-Ir and Pd-Rh). These catalysts were similar to the employed ones in HT synthesis. The Pd-Ir-ReOx $/ \mathrm{SiO}_{2}$ catalyst showed a good $\mathrm{HD}$ yield of $19.1 \%$ for a complete conversion of HMF (see Table 2). However, the formation of 1,5-HD and hexane was higher than the formation of $\mathrm{HD}$, reaching a yield of $22 \%$ and $24.6 \%$, respectively. The Pd-Ir- $\mathrm{ReO} / \mathrm{SiO}_{2}$ and $\mathrm{Ir}-\mathrm{ReOx} / \mathrm{SiO}_{2}$ catalysts provided a similar HD yield (see Table 2), but the formation of 1,5-HD and hexane decreased due to the fact that these catalysts were mainly less active in hydrogenolysis of the HT intermediate product. On the other hand, the DHMTHF was the main product for the Pd-ReOx/ $\mathrm{SiO}_{2}$ catalyst $(72.9 \%)$, followed by the $\mathrm{Ir}-\mathrm{ReOx} / \mathrm{SiO}_{2}, \mathrm{Pt}-\mathrm{ReOx} / \mathrm{SiO}_{2}$ and $\mathrm{Ir}-\mathrm{ReOx} / \mathrm{Al}_{2} \mathrm{O}_{3}$ catalysts. The $\mathrm{HD}$ yield improvement came when the $\mathrm{Pd} / \mathrm{SiO}_{2}$ catalyst, which shows the best performance in the HMF-DHMTHF reaction, and the Ir-ReOx/ $/ \mathrm{SiO}_{2}$ catalysts were used in a double-layered fixed bed $\left(\mathrm{Pd} / \mathrm{SiO}_{2}\right.$ in the upper layer and $\mathrm{Ir}-\mathrm{ReOx} / \mathrm{SiO}_{2}$ in the bottom layer). In this way, the $\mathrm{HD}$ yield increased from $19.1 \%$ to $46.2 \%$ when $\mathrm{Pd} / \mathrm{SiO}_{2}+\mathrm{Ir}-\mathrm{ReOx} / \mathrm{SiO}_{2}$ were used at $100{ }^{\circ} \mathrm{C}, 3 \mathrm{MPa}$ of $\mathrm{H}_{2}$, employing a LHSV of $6 \mathrm{~h}^{-1}$ and mixed solvents of water/THF. The presence of water enhanced the HD yield due to the formation of Re-OH groups, which are Brönsted acid sites precursors, allowing the hydrogenolysis of the $\mathrm{C}-\mathrm{O}$ bond on the DHMTHF intermediate, while THF favored a stronger adsorption of reactants with active sites $[45,56]$. The increase of $\mathrm{H}_{2}$ pressure allows the adsorption of more $\mathrm{H}_{2}$, which favors the HD desorption avoiding its degradation via hydrogenolysis. For this reason, the obtained $\mathrm{HD}$ yield under $7 \mathrm{MPa}$ of pressure was $57.8 \%$ (see Table 2) for the $\mathrm{Pd} / \mathrm{SiO}_{2}+\mathrm{Ir}-\mathrm{ReOx} / \mathrm{SiO}_{2}$ catalyst. Tuteja et al. [55] used monometallic $\mathrm{Pd}$ catalysts and formic acid as $\mathrm{H}_{2}$ source. The highest $\mathrm{HD}$ yield obtained was $42 \%$, slightly below to the obtained ones by Xiao et al. [45], for the $7 \mathrm{wt} \% \mathrm{Pd} / \mathrm{ZrP}$ catalyst at $140{ }^{\circ} \mathrm{C}$ and $21 \mathrm{~h}$. It seems that the obtained yield toward HD is attributed to the low metal dispersion and the high Brönsted/Lewis acid ratio, which are necessary to allow hydrogenation and furan ring-opening, respectively, corroborating the conclusions established by Buntara et al. [26] and Ohyama et al. [48]. Other Pd catalysts under other conditions were tested without improvement of the $\mathrm{HD}$ yield (see Table 2). $\mathrm{Pt}-\mathrm{WO}_{\mathrm{x}} / \mathrm{TiO}_{2}$ and their 
monometallic counterparts were used to produce $\mathrm{HD}$ via $\mathrm{HMF}$ and $\mathrm{DMTHF}$ [41]. The $\mathrm{Pt}-\mathrm{WO}_{\mathrm{x}} / \mathrm{TiO}_{2}$ catalyst, which contains a $10 \mathrm{wt} \%$ of each metal, was able to reach a HD selectivity of $90 \%$ by a sequential reaction (DHMTHF conversion into HT, followed by its hydrogenolysis to produce HD). In this case, the conversions did not exceed $25 \%$. When the process is carried out in the one-pot reaction, the obtained selectivity was around $70 \%$ (in batch reactor: $160{ }^{\circ} \mathrm{C}$ and $5.5 \mathrm{MPa}$ ) and $60 \%$ (in fixed bed reactor: $160^{\circ} \mathrm{C}, 3.5 \mathrm{MPa}$ and WHSV $=1.3 \mathrm{~h}^{-1}$ ) for a conversion of $100 \%$ and $23 \%$, respectively (see Table 2). These authors [41] attributed this good behavior to the hydrogen spillover, which allows separation of $\mathrm{Pt} / \mathrm{TiO}_{2}$ and $\mathrm{WO}_{x} / \mathrm{TiO}_{2}$ species in the catalysts, and synergistic effect between $\mathrm{Pt}$ and $\mathrm{WO}_{\mathrm{x}}$, favored by the reduction capacity of $\mathrm{TiO}_{2}$.

Table 2. Different metal catalysts used for HD production with a summary of reaction conditions and catalytic activity.

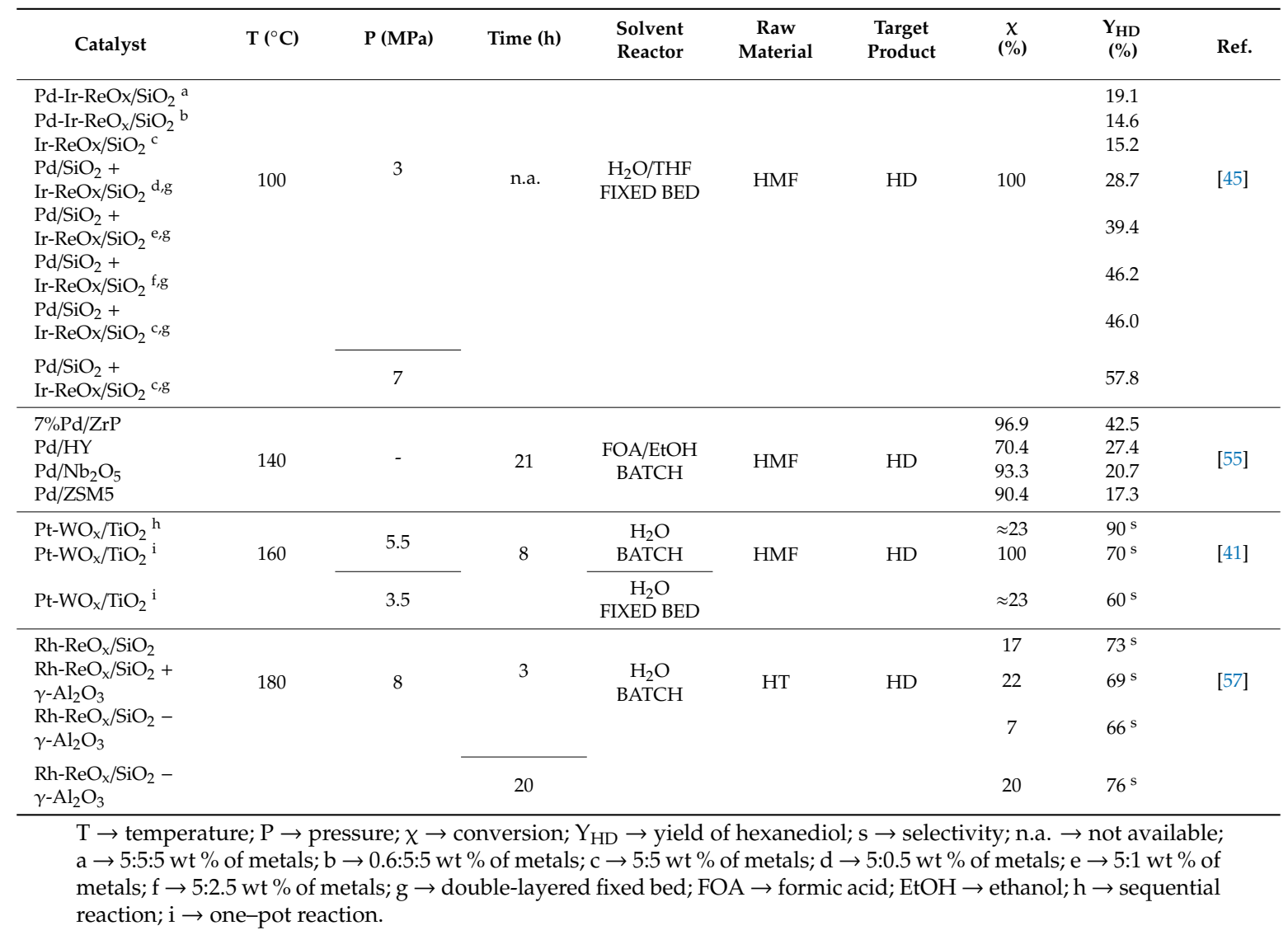

$\mathrm{SiO}_{2}$ and $\gamma-\mathrm{Al}_{2} \mathrm{O}_{3}$ supported $\mathrm{Rh}-\mathrm{ReO}_{\mathrm{x}}$ catalysts [57], which were used for HT production from DHMTHF [26], were also tested in HT conversion into HD. For that purpose, catalysts were previously reduced and then tested in the batch reactor at $180{ }^{\circ} \mathrm{C}$ and $8 \mathrm{MPa} \mathrm{H}_{2}$, using water as a solvent. The $\mathrm{Rh}-\mathrm{ReO}_{x} / \mathrm{SiO}_{2}$ and $\mathrm{Rh}-\mathrm{ReO}_{x} / \mathrm{SiO}_{2}$ combined with $\gamma-\mathrm{Al}_{2} \mathrm{O}_{3}$ catalysts provided highest $\mathrm{HD}$ selectivity, $73 \%$ and $76 \%$, respectively, for a conversion around $20 \%$ in both cases. The carbon balance was mainly closed by the formation of 1,5-HD. The difference for these catalysts were the time on the reaction, being $3 \mathrm{~h}$ for the supported- $\mathrm{SiO}_{2}$ catalyst and $20 \mathrm{~h}$ for the catalyst combined with $\gamma-\mathrm{Al}_{2} \mathrm{O}_{3}$. When the $\mathrm{Rh}-\mathrm{ReO}_{\mathrm{x}} / \mathrm{SiO}_{2}$ catalyst was tested during $20 \mathrm{~h}$, the HT conversion increased to $100 \%$, while HD and 1,5-HD remained constant. The suitable superficial and acidic characteristics of this catalyst [26] could be responsible of the good behavior in the one-step conversion of HT into HD. 


\subsubsection{1,5- and 1,2-Pentanediol Synthesis from FF}

The most extended reaction pathway for the production of $\mathrm{C} 5$ diols from FF is included in Figure 5. The figure also reflects the following products: FFA (furfuryl alcohol), THFA (tetrahydrofurfuryl alcohol), THFF (tetrahydrofurfural), 2-MF (2-methylfuran), 2-MTHF (2-methyltetrahydrofuran), 1,2,5-PT, pentanediols (1,2-PD, 1,4-PD, 1,5-PD), 2-propanol and 1-propanol.

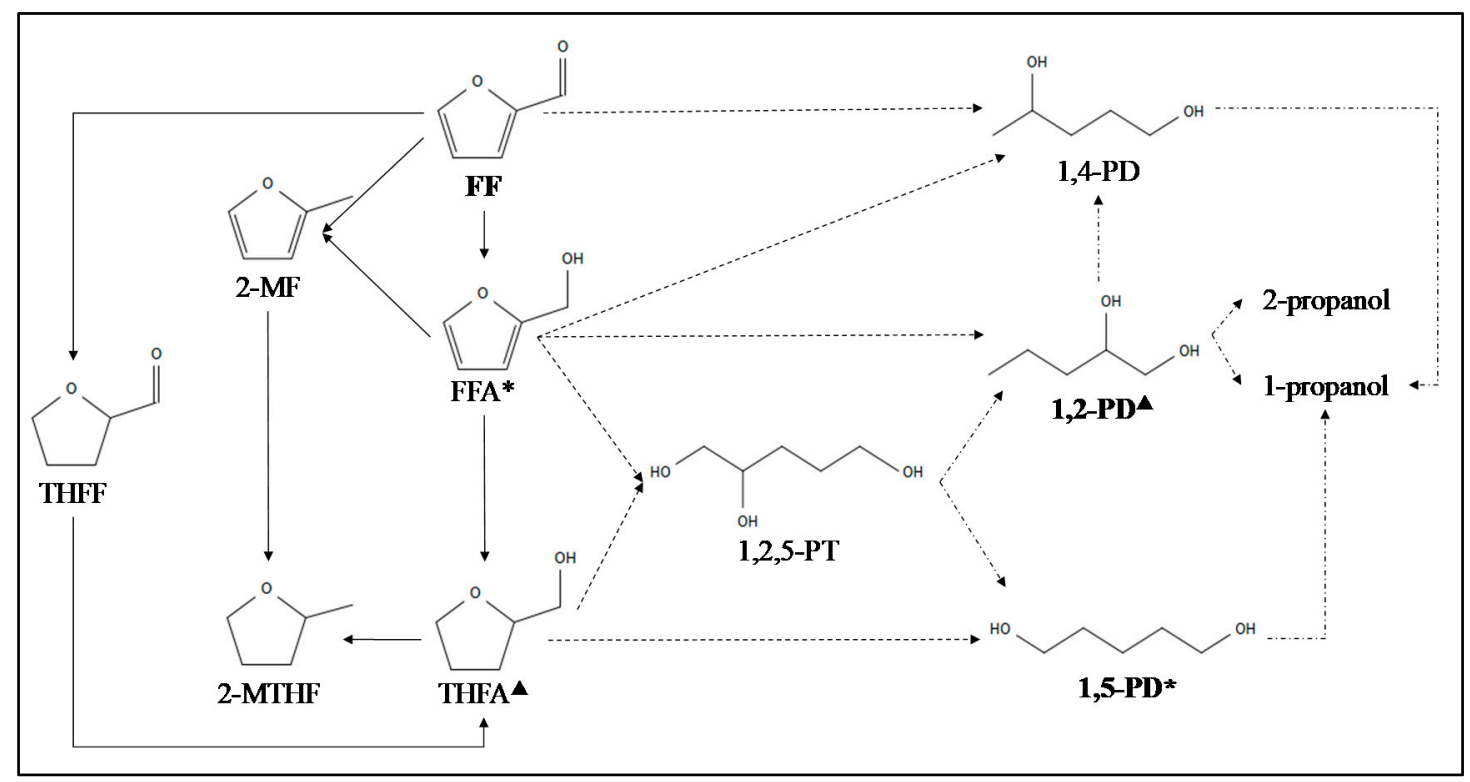

Figure 5. Possible reaction routes and side reactions (solid arrow: hydrogenation; dot arrow: hydrogenation/hydrogenolysis, dash-dot arrow: hydrogenolysis and ${ }^{*}, \mathbf{\Delta}$ : direct synthesis) for pentanediols production adapted from [2,25,58-64].

According to the literature [64], reduced Pd-Ir- $\mathrm{ReO}{ }_{x} / \mathrm{SiO}_{2}$ type solid materials are good candidates for the 1,5-PD production via hydrogenation/hydrogenolysis of FF, following the same criteria as the one for the production of polyols from HMF [26,45]. Liu et al. [64] were capable to obtain a $1,5-\mathrm{PD}$ yield of $71.4 \%$ for the total $\mathrm{FF}$ conversion in one-pot two-step controlled temperature reaction. As it is reflected in Table 3, the optimal conditions were $6 \mathrm{MPa}$ of $\mathrm{H}_{2}, 40{ }^{\circ} \mathrm{C}$ for $8 \mathrm{~h}$ and $100{ }^{\circ} \mathrm{C}$ for $72 \mathrm{~h}$ in each heating step, using the $\mathrm{Pd}-\mathrm{Ir}-\mathrm{ReO}_{\mathrm{x}} / \mathrm{SiO}_{2}$ catalyst. The presence of $\mathrm{Pd}$ and Ir metal species interacting with $\mathrm{ReO}_{x}$ catalyzed the FF hydrogenation and THFA hydrogenolysis, respectively, reaching the similar conclusion as other authors [26,42,45]. They observed that the increase of the first step temperature from 30 to $40{ }^{\circ} \mathrm{C}$ favored the rearrangement reaction of 1,5-PD into 1,4-PD, reducing the 1,5-PD yield [64]. On the contrary, the enhancement of the second step temperature, in the range of $100-120^{\circ} \mathrm{C}$, increased the 1,5-PD yield, without exceeding the highest temperature in order to avoid the over-hydrogenolysis reaction, which is the precursor of the mono-alcohols formation [44] (see Table 3). Moreover, low $\mathrm{H}_{2}$ pressures and the high FF concentration provoke low hydrogenation and FF polymerization rate, respectively. Similar results were obtained using the $\mathrm{Rh}-\mathrm{Ir}-\mathrm{ReO}_{\mathrm{x}} / \mathrm{SiO}_{2}$ catalyst [58], under a higher pressure, $8 \mathrm{MPa}$ of $\mathrm{H}_{2}$, and higher $\mathrm{FF}: \mathrm{H}_{2} \mathrm{O}$ ratio (3:3 in weight). The good performance of this catalyst was ascribed to the presence of the Rh-Ir alloy [25,27]. Supported $\mathrm{Ni}$ and $\mathrm{Cu}$ non-noble metal catalysts were also employed in hydrogenation/hydrogenolysis of THFA [63] and FFA [59], respectively. However, Ni catalysts provided 1,5-PD selectivities below 50\% in the established conditions [59,63]. When Ni/HZSM-5 catalysts were used [63], the highest 1,5-PD selectivity achieved was $36 \%$ for $17 \%$ of THFA conversion at conditions reflected in Table 3 . It seems that THFA is transformed into 1,5-PD, which suffers from hydrogenolysis and circulation to produce tetrahydropyran. $\mathrm{Ni} / \mathrm{SiO}_{2}$ and $\mathrm{Ni} / \mathrm{Al}_{2} \mathrm{O}_{3}$ catalysts presented 1,5-PD selectivity below the obtained ones by Ni/HZSM- 5 at different reaction conditions $[59,63]$. 
Table 3. Different catalysts used for PD production with a summary of reaction conditions and catalytic activity, using an autoclave reactor.

\begin{tabular}{|c|c|c|c|c|c|c|c|c|c|}
\hline Catalyst & $\mathrm{T}\left({ }^{\circ} \mathrm{C}\right)$ & Time (h) & P (MPa) & Solvent & $\begin{array}{c}\text { Raw } \\
\text { Material }\end{array}$ & $\begin{array}{c}\text { Target } \\
\text { Product }\end{array}$ & $\begin{array}{c}x \\
(\%)\end{array}$ & $\begin{array}{l}\mathrm{Y}_{\mathrm{PD}} \\
(\%)\end{array}$ & Ref. \\
\hline \multirow{4}{*}{$\mathrm{Pd}(0.66)-\mathrm{Ir}-\mathrm{ReO}_{\mathrm{x}} / \mathrm{SiO}_{2}$} & $40-100$ & $8-72$ & \multirow{3}{*}{6} & \multirow{4}{*}{$\mathrm{H}_{2} \mathrm{O}$} & \multirow{4}{*}{$\mathrm{FF}$} & \multirow{4}{*}{ 1,5-PD } & 100 & 71.4 & \multirow{4}{*}{ [64] } \\
\hline & $30-160$ & $2-24$ & & & & & 100 & 60.3 & \\
\hline & $40-160$ & $2-24$ & & & & & 100 & 63.2 & \\
\hline & $40-120$ & $2-24$ & 2 & & & & 100 & 11.1 & \\
\hline \multirow{4}{*}{$\mathrm{Rh}(0.66)-\mathrm{Ir}-\mathrm{ReO}_{\mathrm{x}} / \mathrm{SiO}_{2}$} & $30-100$ & $8-24$ & \multirow{3}{*}{6} & \multirow{4}{*}{$\mathrm{H}_{2} \mathrm{O}$} & \multirow{4}{*}{$\mathrm{FF}$} & \multirow{4}{*}{ 1,5-PD } & 100 & 66.4 & \multirow{4}{*}{ [58] } \\
\hline & $40-140$ & $8-24$ & & & & & 100 & 37.7 & \\
\hline & \multirow{2}{*}{$40-100$} & \multirow{2}{*}{$8-24$} & & & & & 100 & 65.8 & \\
\hline & & & 8 & & & & 100 & 71.1 & \\
\hline $\begin{array}{l}\mathrm{Ni} / \mathrm{HZSM}-5 \\
\mathrm{Ni} / \mathrm{SiO}_{2} \\
\mathrm{Ni} / \mathrm{Al}_{2} \mathrm{O}_{3}\end{array}$ & 250 & 4 & 3.4 & $\mathrm{H}_{2} \mathrm{O}$ & THFA & 1,5-PD & $\begin{array}{l}17 \\
7.9 \\
6.1 \\
\end{array}$ & $\begin{array}{l}36.6^{\mathrm{s}} \\
33.1^{\mathrm{s}} \\
14.7^{\mathrm{s}}\end{array}$ & [63] \\
\hline $\begin{array}{l}10 \mathrm{Cu} / \mathrm{Al}_{2} \mathrm{O}_{3} \\
10 \mathrm{Cu} / \mathrm{Al}_{2} \mathrm{O}_{3} \text { a }\end{array}$ & 140 & 6 & 8 & $\mathrm{EtOH}$ & FFA & 1,5-PD & $\begin{array}{l}60.4 \\
85.5\end{array}$ & $\begin{array}{l}22.7^{\mathrm{s}}\left(71.3^{\mathrm{e}}\right) \\
22.2^{\mathrm{s}}\left(70^{\mathrm{e}}\right)\end{array}$ & [59] \\
\hline \multirow{4}{*}{ Pt/hydrotalcite } & 150 & \multirow{4}{*}{3} & \multirow{4}{*}{8} & \multirow{2}{*}{ 2-PrOH } & \multirow{4}{*}{$\mathrm{FF}$} & \multirow{4}{*}{ 1,2-PD } & 100 & $73^{\mathrm{s}}\left(81^{\mathrm{e}}\right)$ & \multirow{4}{*}{ [65] } \\
\hline & 100 & & & & & & 100 & $43^{\mathrm{s}}\left(56^{\mathrm{e}}\right)$ & \\
\hline & \multirow{2}{*}{150} & & & $\mathrm{H}_{2} \mathrm{O}$ & & & 100 & $18^{\mathrm{s}}\left(24^{\mathrm{e}}\right)$ & \\
\hline & & & & $\mathrm{EtOH}$ & & & 100 & $71^{\mathrm{s}}\left(80^{\mathrm{e}}\right)$ & \\
\hline $\begin{array}{l}\mathrm{Pt} / \mathrm{Al}_{2} \mathrm{O}_{3}+\mathrm{NaBH}_{4} \\
\mathrm{MIL}-53-\mathrm{AI}-\mathrm{NH}_{2}+\mathrm{NaBH}_{4} \\
\mathrm{Pt} / \mathrm{Al}_{2} \mathrm{O}_{3}-\mathrm{MIL}-53-\mathrm{AI}-\mathrm{NH}_{2}+ \\
\mathrm{NaBH}_{4}\end{array}$ & 45 & 8 & 0.45 & $\mathrm{H}_{2} \mathrm{O}$ & $\mathrm{FF}$ & 1,5-PD & 100 & $\begin{array}{l}18.0 \\
30.1 \\
75.2\end{array}$ & [66] \\
\hline 3Pd/MMT & 220 & 3.5 & 5 & IPA & FF & 1,2-PD & 100 & $66^{\mathrm{s}}\left(68^{\mathrm{f}}\right)$ & [62] \\
\hline $\begin{array}{l}\mathrm{Ru} / \mathrm{OMS}-2 \\
\mathrm{Pd} / \mathrm{OMS}-2\end{array}$ & 165 & 8 & 3 & $\mathrm{MeOH}$ & FF & 1,2-PD & $\geq 99$ & $\begin{array}{l}87 \\
76 \\
\end{array}$ & [67] \\
\hline $\begin{array}{l}\mathrm{NbPO}(\text { synthesized at } \mathrm{pH}=7 \text { ) } \\
\mathrm{NbPO} \text { (synthesized at } \mathrm{pH}=5 \text { ) } \\
\mathrm{Nb}_{2} \mathrm{O}_{5}\end{array}$ & 150 & 3 & 4 & $\begin{array}{c}\mathrm{H}_{2} \mathrm{O} / \\
\text { GVL-Cyclo }\end{array}$ & xylose & 1,2-PD & $\begin{array}{l}100 \\
100 \\
100\end{array}$ & $\begin{array}{l}19.1^{\mathrm{s}}\left(25.6^{\mathrm{f}}\right) \\
17.5^{\mathrm{s}}\left(22.6^{\mathrm{f}}\right) \\
6.5^{\mathrm{s}}\left(8.8^{\mathrm{f}}\right)\end{array}$ & [68] \\
\hline
\end{tabular}

Table 3 indicates that $\mathrm{Cu} / \mathrm{Al}_{2} \mathrm{O}_{3}$ catalysts are able to provide 1,5-PD selectivities close to obtained ones with Ni catalysts. They offer higher conversions of FFA and 1,2-PD selectivities at $140{ }^{\circ} \mathrm{C}, 6 \mathrm{MPa}$ of $\mathrm{H}_{2}$ and $8 \mathrm{~h}$. Concretely, the $10 \mathrm{Cu} / \mathrm{Al}_{2} \mathrm{O}_{3}$ catalyst, with a high $\mathrm{Cu}$ dispersion and acidic support, shows the best performance in terms of conversion (85.5\%) and pentanediols selectivity (70\%) [59].

When Pt supported on hydrotalcite were used, the 1,2-PD yield increased up to 73\%, in detriment of 1,5-PD, for a total conversion of $\mathrm{FF}$ at $150{ }^{\circ} \mathrm{C}$ and $3 \mathrm{MPa}$ of $\mathrm{H}_{2}$, using 2-propanol instead of another kind of solvent [65] (see Table 3). This yield trend was the opposite when lower reaction temperatures were used. The combination of hydrotalcite basic sites, which promote the formation of polar hydrogen species attacking selectively the $\mathrm{C}-\mathrm{O}$ bond, and $\mathrm{Pt}$, which offers hydrogenation capacity, provided a catalyst with good activity and yield to target products. However, when $\mathrm{Pt} / \mathrm{Al}_{2} \mathrm{O}_{3}$ embedded in a metal organic framework, MIL-53-AI-NH $\mathrm{N}_{2}$, was used with $\mathrm{NaBH}_{4}$ as a hydrogen donor, a 1,5-PD yield of $75,2 \%$ were obtained at $45^{\circ} \mathrm{C}, 0.45 \mathrm{MPa}$ of $\mathrm{H}_{2}$ and $8 \mathrm{~h}$ using water as a solvent, without the presence of 1,2-PD [66].

The Pd/MMT catalyst, with Pd nanoparticles and Brönted-Lewis acidity, necessary for hydrogenolysis [48,68], presented also good performance in 1,2-PD production when high temperatures $\left(220^{\circ} \mathrm{C}\right)$ and pressures $(3.5 \mathrm{MPa})$ were used [62]. In this case, significant quantities of 1,4-PD are also formed without the presence of 1,5-PD. Even the use of noble metal catalysts supported on OMS-2 (octahedral molecular sieve), with basic sites, seems to be a good alternative to produce 1,2-PD from FF [67]. Concretely the Ru/OMS-2 catalyst provided a 1,2-PD selectivity of $87 \%$ for a complete conversion of $\mathrm{FF}$ at $160{ }^{\circ} \mathrm{C}, 3 \mathrm{MPa}$ of $\mathrm{H}_{2}$ and $8 \mathrm{~h}$. The Pd/OMS-2 catalyst also provided good performance in terms of selectivity toward 1,2-PD (76\%), but below the ones obtained by the Ru catalyst. Catalysts without the metallic phase, such as $\mathrm{NbPO}$, were active in one-pot xylose conversion 
and more selective toward 1,2-PD (maximum value 19.1\%) when compared with $\mathrm{Nb}_{2} \mathrm{O}_{5}$ catalysts in an aqueous biphasic system, because of their high Lewis acidity [68].

\section{Anhydride of Acids: Maleic Anhydride (MAN)}

In the last years different conversion routes have been technically demonstrated to turn this petrochemical into a renewable chemical by the oxidation of different renewable platforms like 1-butanol [69], levulinic acid [70], HMF [33,71-73] and FF [13,31,74-81] using $\mathrm{O}_{2}$ (see Table 4). Moreover, contrary to the current conventional process carried out in the gas phase, depending on the reaction conditions and the used reactant, the MAN production can be performed in the aqueous or gas phase. If the reaction is carried out in the aqueous phase, maleic acid is produced instead of MAN. However, both products can be efficiently converted into each other via reversible dehydration/hydration steps.

Pavarelli et al. performed the oxidehydration of butanol [69]. Two sequential steps are involved in this reaction: (i) 1-butanol dehydration to 1-butene (catalyzed by acid sites) and (ii) the oxidation of 1-butene into MAN (catalyzed by redox sites). Thus, a bifunctional catalyst able to dehydrate butanol and oxidate 1-butane is required; in this case a vanadyl pyrophosphate catalyst was employed in a continuous flow reactor achieving maximum MAN yields of $39 \%$ and total conversion at $340-360{ }^{\circ} \mathrm{C}$. Levulinic acid is another biomass-derived platform chemical that could play a central role in emerging industries as an intermediate that facilitates the production of different biochemicals. Chatzidimitriou et al. [70] used levulinic acid as the raw material to produce MAN using $\mathrm{VO}_{\mathrm{x}}$ supported on $\mathrm{SiO}_{2}$ as a catalyst. They tested different reaction conditions obtaining the best results $(100 \%$ of levulinic acid conversion and $71 \%$ of MAN yield) at $325^{\circ} \mathrm{C}$ and $3.9 \mathrm{~min}$ of contact time. Moreover, they describe the possible reaction pathway where the levulinic acid is oxidized into formaldehyde and succinic acid and the later one can reversibly form its anhydride and then the MAN by oxidative dehydrogenation steps.

The use of HMF and FF as raw materials is the most investigated route for the production of MAN since these two reactants are two of the most promising biobased platform molecules so far $[2,13,82]$. With regards to the HMF, Du et al. [33] developed several catalytic systems in the liquid phase using acetonitrile as a solvent. Using bis(acetylacetone)oxovanadium $\left(\mathrm{VO}(\mathrm{ACAC})_{2}\right)$ as a catalyst, $52 \%$ of MAN yield was achieved at $90{ }^{\circ} \mathrm{C}, 1 \mathrm{MPa}$ and $4 \mathrm{~h}$ of reaction time. They also tried to use some other transition metal catalysts such as copper sulphate, cobalt acetate, ferrous sulphate but they did not succeeded ( $<5 \%$ MAN yield), concluding that vanadium species are crucial for MAN production from HMF. Lan et al. [71] tested the usage of vanadium-substituted heteropolyacid catalyst using acetonitrile and achieved $41.8 \%$ of MAN yield after $8 \mathrm{~h}$ at $90{ }^{\circ} \mathrm{C}$ and under $1 \mathrm{MPa}$. They also tried to discover the reaction mechanism testing the oxidation of different published HMF oxidation intermediates (FDCA, 2,5-diformylfuran (DFF), 5-formyl-2-furancarboxylic acid (FFCA), and 5-hydroxymethyl-2-furancarboxylic acid (HMFCA)) in the same conditions as with HMF. They concluded that none of them has a chance to serve as intermediates in MAN formation. Li et al. [83] also used vanadium based catalysts $\left(\mathrm{V}_{2} \mathrm{O}_{5}, \mathrm{VOHPO}_{4},(\mathrm{VO})_{2} \mathrm{P}_{2} \mathrm{O}_{7}\right.$ and $\left.\mathrm{Mo}_{9} \mathrm{~V}_{3} \mathrm{O}_{8}\right)$ and reported total $\mathrm{HMF}$ conversion with MAN + maleic acid yields around $75-79 \%$ at $100{ }^{\circ} \mathrm{C}, 4 \mathrm{~h}$ and under $1 \mathrm{MPa}$. Although they tested different solvents, acetic acid was the one that offered the best results. Moreover, these authors tested the direct conversion of fructose to MAN achieving 50\% of MAN yield in the above described conditions (fructose dehydration was catalyzed by $\mathrm{HCl}$ in 2-propanol). Lv et al. [72,84] use a vanadium based catalyst achieving the best results with those that were immobilized onto the Schiff base modified graphene oxide (GO) using HMF diluted in acetic acid. The achieved yield was 95.3\% (sum of MAN and hydrolyzed maleic anhydride in 1:2.5 proportion, respectively) with a total HMF conversion at conditions reflected in Table 4. Chai et al. [85] also conducted HMF oxidation to maleic acid + MAN reaction using a graphene oxide supported vanadium catalyst (V-GO). They tested the reaction using different solvents $\left(\mathrm{GVL}, \mathrm{HAc}\right.$ and $\left.\mathrm{H}_{2} \mathrm{O}\right)$ being the use of GVL the one that showed the best results (53.7\% of maleic acid+MAN yield and $97.8 \%$ of HMF conversion at $90{ }^{\circ} \mathrm{C}$, $2 \mathrm{MPa}$ of $\mathrm{O}_{2}$ atmosphere and $4 \mathrm{~h}$ of reaction time). More recently, Jia et al. [86] carried out a more novel 
approach to produce MAN using (formate) methyl]furfural (FMF) as the raw material and pure oxygen as the oxidant over $\alpha-\mathrm{MnO}_{2} / \mathrm{Cu}\left(\mathrm{NO}_{3}\right)_{2}$ with the assistance of $\mathrm{K}_{2} \mathrm{~S}_{2} \mathrm{O}_{8}$ (KPS). FMF is presented as a more stable and more hydrophobic compound than $\mathrm{HMF}$, facilitating its separation from the reaction mixture. The tests were performed using a mixture of water and $\mathrm{MeCN}$ as a solvent at $90{ }^{\circ} \mathrm{C}, 5 \mathrm{~h}$ of reaction time and atmospheric pressure. Results showed 100\% of conversion of FMF and a maleic acid yield of $89 \%$. Moreover, the same catalyst was reused in three different cycles showing almost the same results in all of them.

As well as in the HMF case, liquid-phase FF oxidation using $\mathrm{O}_{2}$ at high pressures (above 1 $\mathrm{MPa}$ [2]) has been also studied. In general more studies are reported using this raw material than with $\mathrm{HMF}$, but $60 \%$ is the highest achieved MAN yield reported in all the cases. Moreover, the employed catalyst propoters and solvents make most of these processes far from being technoeconomically viable, reporting some deactivation problems due to leaching phenomena when using acetic acid as a solvent [72]. Thus, Huang et al. [80] reported MAN formation using metallopor phyrin catalysts $(\mathrm{FeT}(\mathrm{p}-\mathrm{Cl}) \mathrm{PP} \mathrm{Cl})$ in the aqueous/organic biphase system achieving $44 \%$ of the MAN yield and $95 \%$ of the FF conversion at $90^{\circ} \mathrm{C}, 1.2 \mathrm{MPa}$ and $4 \mathrm{~h}$. Guo et al. [87] achieved 34.5\% of the MAN yield and 50.4\% of the FF conversion using a phosphomolybdic acid catalyst in the aqueous/organic (tetrachloroethane) biphase system $\left(110^{\circ} \mathrm{C}, 2 \mathrm{MPa}\right.$ and $\left.14 \mathrm{~h}\right)$. Lan et al. [76] reported a 54\% MAN yield and $98.5 \%$ of the FF conversion using $\mathrm{H}_{5} \mathrm{PV}_{2} \mathrm{Mo}_{10} \mathrm{O}_{40}$ and $\mathrm{Cu}\left(\mathrm{CF}_{3} \mathrm{SO}_{3}\right)_{2}$ catalysts using acetic acid as the solvent at $110{ }^{\circ} \mathrm{C}$, $14 \mathrm{~h}$ and under $2 \mathrm{MPa}$. More recently, Soták et al. [88] reported their study where the CaCu-phosphate catalyst showed the best catalytic performance (37.3\% MAN yield) at $115{ }^{\circ} \mathrm{C}$ and $0.8 \mathrm{MPa}$ using water as the solvent.

Another aqueous phase oxidation option reported in the open literature is using $\mathrm{H}_{2} \mathrm{O}_{2}$, as an oxidizing agent, instead of $\mathrm{O}_{2}$. López-Granados et al. has published several papers where using a commercial titanium silicate catalyst (TS-1), reaching a 70\% of MAN yield with 5 wt \% of the FF conversion in water, $5 \mathrm{wt} \%$ of the catalyst (titanium silicate), $\mathrm{H}_{2} \mathrm{O}_{2} / \mathrm{FF}$ mol ratio of $7.5,50{ }^{\circ} \mathrm{C}$ and $24 \mathrm{~h}$ of residence time [74]. Recently, some other authors have also employed $\mathrm{H}_{2} \mathrm{O}_{2}$ in the production of MAN [77-79,91,92]. However, in spite of the promising catalytic activity that offers the usage of $\mathrm{H}_{2} \mathrm{O}_{2}$, its usage could be restricted due to economic reasons [93].

Finally, oxidation of FF in the gas phase is also reported using different vanadium oxide-based catalysts (V oxide, V-Mo and V-Bi mixed oxides); however, most of the references date from the first part of the 20th century [31,89,94-96]. More recently, López-Granados et al. has reported some promising results $[31,89]$ using vanadium oxide supported on alumina. Thus, at $300{ }^{\circ} \mathrm{C}$ and using $1 \%$ of $\mathrm{FF}$ in air (vol\%) and a $\mathrm{O}_{2} / \mathrm{FF}$ molar ratio of 20 , an initial yield well above $70 \%$ was obtained. However, the deactivation of the catalyst is unavoidable due to the deposition of resins on the catalyst surface. More recently, Santander et al. [90] have studied the effect of different supports $\left(\mathrm{SiO}_{2}\right.$, $\gamma-\mathrm{Al}_{2} \mathrm{O}_{3}, \mathrm{ZrO}_{2}$ and $\mathrm{TiO}_{2}$ ) on the oxidation of $\mathrm{FF}$ to MAN using vanadia catalysts. They concluded that $\mathrm{SiO}_{2}$ and $\gamma-\mathrm{Al}_{2} \mathrm{O}_{3}$ are the ones offering the highest maleic acid yield (50\%), but when the oxidation potential of the reaction feed was decreased (lower $\mathrm{O}_{2} / \mathrm{FF}$ ratios) comparable maleic acid yields were obtained with $\mathrm{V}_{2} \mathrm{O}_{5} / \mathrm{SiO}_{2}$ and $\mathrm{V}_{2} \mathrm{O}_{5} / \gamma-\mathrm{Al}_{2} \mathrm{O}_{3}$ catalysts. Despite achieving lower yields than the group of López-Granados, Santander et al. did not observe any deactivation after $20 \mathrm{~h}$ on stream. 
Table 4. Reported catalysts in the production of maleic anhydride from renewable sources with summary of reaction conditions and catalytic activity.

\begin{tabular}{|c|c|c|c|c|c|c|c|}
\hline Catalyst & $\mathrm{T}\left({ }^{\circ} \mathrm{C}\right)$ & $\begin{array}{c}\text { Phase } \\
\text { (Solvent) }\end{array}$ & $\begin{array}{l}\text { Oxidating } \\
\text { Agent }\end{array}$ & $\begin{array}{c}\text { Raw } \\
\text { Material }\end{array}$ & $\begin{array}{c}x \\
(\%)\end{array}$ & $\underset{(\%)}{Y_{\text {MAN }}}$ & Ref. \\
\hline $\begin{array}{c}\text { Vanadyl pyro- } \\
\text { phosphate (VPP) }\end{array}$ & $340-360$ & G & $\mathrm{O}_{2}$ & Butanol & 100 & 39 & [69] \\
\hline $\mathrm{VO}_{\mathrm{x}} / \mathrm{SiO}_{2}$ & 325 & G & $\mathrm{O}_{2}$ & $\begin{array}{l}\text { Levulinic } \\
\text { acid }\end{array}$ & 100 & 71 & [70] \\
\hline $\mathrm{VO}(\mathrm{ACAC})_{2}$ & 90 & $\mathrm{~L}(\mathrm{ACN})$ & $\mathrm{O}_{2}$ & HMF & 99 & 52 & {$[33]$} \\
\hline $\mathrm{H}_{5} \mathrm{PV}_{2} \mathrm{Mo}_{10} \mathrm{O}_{40} \cdot \times \mathrm{H}_{2} \mathrm{O}$ & 90 & $\mathrm{~L}(\mathrm{ACN})$ & $\mathrm{O}_{2}$ & HMF & $>99$ & 41.8 & [71] \\
\hline $\begin{array}{c}\mathrm{V}_{2} \mathrm{O}_{5} \\
\mathrm{VOHPO} \\
(\mathrm{VO})_{2} \mathrm{P}_{2} \mathrm{O}_{7} \\
\mathrm{Mo}_{9} \mathrm{~V}_{3} \mathrm{O}_{8}\end{array}$ & 100 & $\begin{array}{c}\mathrm{L} \\
\text { (HAc) }\end{array}$ & $\begin{array}{c}\mathrm{O}_{2} \\
(1 \mathrm{MPa})\end{array}$ & $\mathrm{HMF}$ & $\begin{array}{l}99 \\
99 \\
99 \\
97\end{array}$ & $\begin{array}{c}75^{\mathrm{a}}(1.9: 1) \\
78^{\mathrm{a}}(2.0: 1 \\
79^{\mathrm{a}}(1.9: 1) \\
69^{\mathrm{a}}(2.6: 1)\end{array}$ & [83] \\
\hline $\begin{array}{c}\mathrm{V}_{2} \mathrm{O}_{5} \\
\mathrm{VO}(\mathrm{ACAC})_{2} \\
(10 \%) \mathrm{V}_{2} \mathrm{O}_{5} / \mathrm{SiO}_{2} \\
\mathrm{VO}-\mathrm{NH}_{2}-\mathrm{GO}\end{array}$ & 90 & $\begin{array}{c}\mathrm{L} \\
\text { (HAc) }\end{array}$ & $\begin{array}{c}\mathrm{O}_{2} \\
(2 \mathrm{MPa})\end{array}$ & HMF & $\begin{array}{l}99.1 \\
99.8 \\
99.8 \\
99.8\end{array}$ & $\begin{array}{l}48.3^{\mathrm{a}} \\
(1: 5.8) \\
55.2^{\mathrm{a}} \\
(1: 3.8) \\
64.5^{\mathrm{a}} \\
(1: 4.2) \\
95.3^{\mathrm{a}} \\
(1: 2.5)\end{array}$ & {$[72,84]$} \\
\hline (V-GO) & 90 & $\begin{array}{c}\mathrm{L} \\
(\mathrm{GVL})\end{array}$ & $\begin{array}{c}\mathrm{O}_{2} \\
(2 \mathrm{MPa})\end{array}$ & HMF & 97.8 & 53.7 & [85] \\
\hline $\begin{array}{c}\alpha-\mathrm{MnO}_{2} / \mathrm{Cu}\left(\mathrm{NO}_{3}\right)_{2}+ \\
\mathrm{K}_{2} \mathrm{~S}_{2} \mathrm{O}_{8}\end{array}$ & 90 & $\begin{array}{c}\mathrm{L} \\
\left(\mathrm{H}_{2} \mathrm{O}+\right. \\
\mathrm{MeCN})\end{array}$ & $\begin{array}{c}\mathrm{O}_{2} \\
(1 \mathrm{MPa})\end{array}$ & FMF & 100 & 89 & [86] \\
\hline $\mathrm{FeT}(\mathrm{p}-\mathrm{Cl}) \mathrm{PPCl}$ & 90 & $\begin{array}{c}\mathrm{L} \\
\left(\mathrm{H}_{2} \mathrm{O} / \mathrm{Org}\right)\end{array}$ & $\begin{array}{c}\mathrm{O}_{2} \\
(1.2 \mathrm{MPa})\end{array}$ & FF & 95 & 44.0 & [80] \\
\hline $\mathrm{H}_{3} \mathrm{PMo}_{12} \mathrm{O}_{40} \times 3 \mathrm{H}_{2} \mathrm{O}$ & 110 & L (TCE) & $\begin{array}{c}\mathrm{O}_{2} \\
(2 \mathrm{MPa}) \\
\end{array}$ & FF & 50.4 & 34.5 & [87] \\
\hline $\begin{array}{c}\mathrm{H}_{5} \mathrm{PV}_{2} \mathrm{Mo}_{10} \mathrm{O}_{40} \text { and } \\
\mathrm{Cu}\left(\mathrm{CF}_{3} \mathrm{SO}_{3}\right)_{2}\end{array}$ & 110 & L (HAc) & $\begin{array}{c}\mathrm{O}_{2} \\
(2 \mathrm{MPa}) \\
\end{array}$ & FF & 98.5 & 54.0 & [76] \\
\hline $\mathrm{CaCu}_{2} \mathrm{P}_{2} \mathrm{O}_{7}$ & 115 & $\mathrm{~L}\left(\mathrm{H}_{2} \mathrm{O}\right)$ & $\begin{array}{c}\mathrm{O}_{2} \\
(0.8 \mathrm{MPa})\end{array}$ & FF & $\approx 55.0$ & 37.3 & [88] \\
\hline TS-1 & 50 & $\mathrm{~L}\left(\mathrm{H}_{2} \mathrm{O}\right)$ & $\mathrm{H}_{2} \mathrm{O}_{2}$ & FF & 100 & 70 & [74] \\
\hline $\mathrm{V}_{2} \mathrm{O}_{5} / \gamma-\mathrm{Al}_{2} \mathrm{O}_{3}$ catalysts & 300 & G & $\mathrm{O}_{2}$ & FF & $\approx 100$ & 70 & {$[31,89]$} \\
\hline $\mathrm{V}_{2} \mathrm{O}_{5} / \gamma-\mathrm{Al}_{2} \mathrm{O}_{3}$ & 320 & G & $\mathrm{O}_{2}$ & FF & $\approx 100$ & 50 & [90] \\
\hline
\end{tabular}

\section{Alkoxymethylfurfurals (AMF) from HMF Etherification with Different Alcohols}

All the AMF compounds are obtained by etherification of HMF using different alcohols [97,98]. Nevertheless, fructose or glucose are also used since some authors claim that the direct use of HMF as raw material is economically unfeasible [99]. As it can be observed in Figure 6, which reflects the most usual reactions, the formation of AMFs is due to the integration of an alkoxy group on the HMF structure substituting its $\mathrm{OH}$ group [23]. These compounds can be 5-isopropoxymethylfurfural (IPMF), 5-tert-butoxymethylfurfural (TBMF), 5-octyloxymethylfurfural (OMF), 5-dodecyloxymethylfurfural (DDMF) and 5-hexadecyloxymethylfurfural (HDMF). 


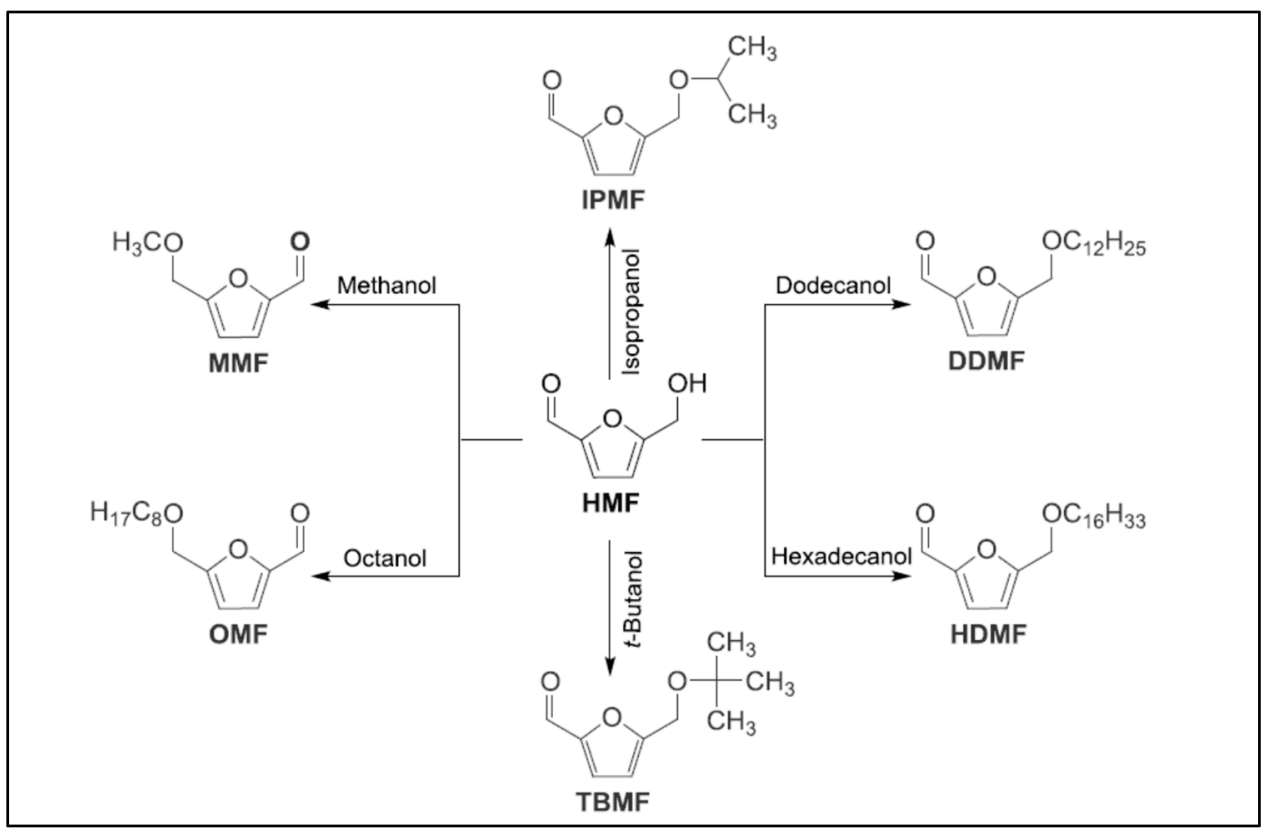

Figure 6. Etherification of HMF with various alcohols [23].

Another symmetrical ether, the OBMF, can be produced by the HMF self-etherification or by Williamson reaction using HMF and 5-chloromethylfurfural [23] (see Figure 7). Depending on the operating conditions different byproducts, such as alkyl levulinate and dyalkylacetals [100], can be obtained.

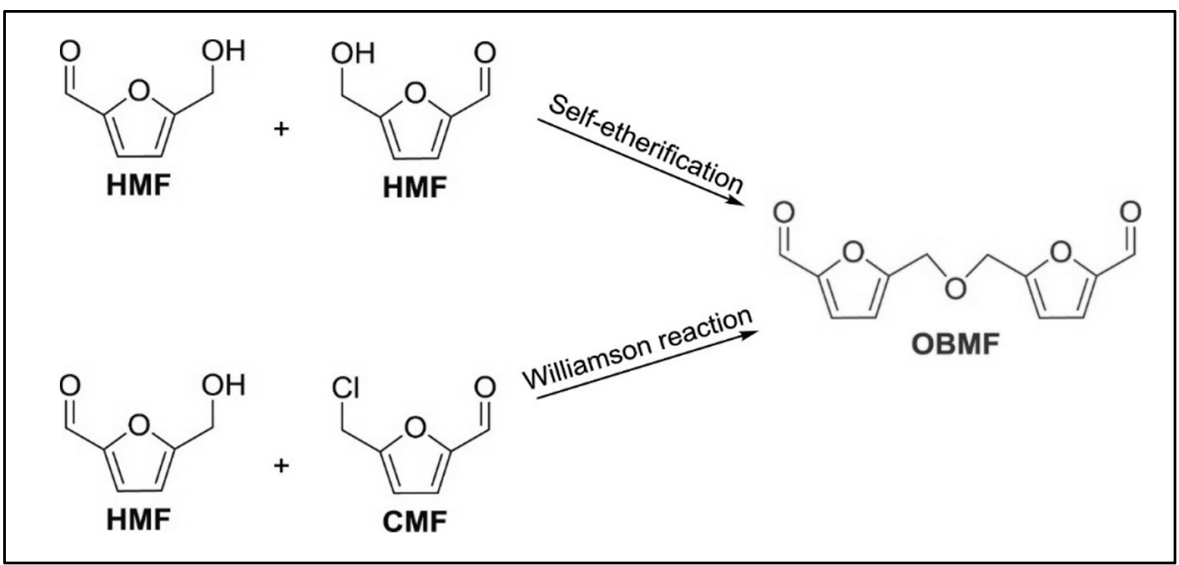

Figure 7. OBMF production for a self-etherification [23].

The use of a higher molecular weight alcohols lead to the formation of higher molecular weight AMF compounds. These ones present a better low-temperature flowing properties when compared with low molecular weight AMF, such as methoximetilfurfural (MMF) or EMF [97,98].

The most used catalysts in the etherification reactions are acid-catalysts, which are identified as the key point in this process [99]. Although some homogeneous acid catalysts have been proposed [101-106], the use of heterogeneous catalysts (heteropolyacids [107,108], their supported nanoparticles [109,110], acid-modified mesoporous silica materials [3,111], GO [112], zeolites and resins [113]) seems to be promising and more adequate in order to avoid the well-known disadvantages presented by homogeneous acid catalysts [114]. Recent studies have evidenced that the type and strength of the acid sites, as well as the operating conditions and the used cosolvent, influence the reaction path and the selectivity [111]. 
Among the possible AMF compounds, many studies are focused on the EMF production, because of its potential use as biofuel. Most of these studies are carried out in batch conditions. Some authors [115] suggested that the EMF yield ratio depends on the relative Lewis:Brönsted acid sites ratio of the catalyst. Strong Brönsted and Lewis acids favor the formation of levulinic acid esters as byproducts. These authors [115] used SBA-15 zeolites in its protonated form and MCM- 41 type zeolites. In both cases, the acid sites were tuned by introducing $\mathrm{Zr}$ and $\mathrm{S}$ and adjusting the $\mathrm{Si} / \mathrm{Al}$ ratio, respectively. The catalytic test was developed at $140{ }^{\circ} \mathrm{C}$ for $5 \mathrm{~h}$ under autogenous pressure, achieving $76 \%$ EMF yield and total HMF conversion with SBA-15 doped with $\mathrm{Zr}$, as it can be observed in Table 5 .

Table 5. Reported catalysts in the production of the ethers from renewable sources with a summary of the reaction conditions and catalytic activity.

\begin{tabular}{|c|c|c|c|c|c|}
\hline Catalyst & Solvent & Feed & $\mathrm{T}\left({ }^{\circ} \mathrm{C}\right)$ & $Y_{\text {EMF }}(\%)$ & Ref. \\
\hline Z-SBA-15 & THF & $\mathrm{HMF}$ & 140 & 76 & [115] \\
\hline $\mathrm{H}_{3} \mathrm{PW}_{12} \mathrm{O}_{40}$ & THF & HMF & 130 & 76 & [107] \\
\hline Phosphotungstic acid & DMSO & Fructose & 140 & 64 & [108] \\
\hline Silica sulfate & & HMF & & 83.8 & \\
\hline Silica sulfate & DMSO & Fructose & 100 & 63.1 & [3] \\
\hline Silica sulfate & & Sucrose & & 34.9 & \\
\hline Pr-SO ${ }_{3} \mathrm{H}-\mathrm{SBA}-15$ & DMSO & HMF & 116 & 63.4 & [111] \\
\hline Graphene oxides & DMSO & HMF & 100 & 92 & [112] \\
\hline
\end{tabular}

Yang et al. [107] used heteropolyacids, such as $\mathrm{H}_{3} \mathrm{PW}_{12} \mathrm{O}_{40}$ (HPW), to transform fructose into EMF. This type of catalyst is common in the carbohydrate conversion [116-118] and etherification processes [119] due to their well-defined structure, their Brönsted acidity, the possibility to modify their acid-base properties, the ability to accept and release electrons and the high proton mobility [120]. However, they suggest that EMF selectivity cannot only depend on the acid character of the catalyst, but also on the reaction time, reaction temperature and catalyst amount [107]. Therefore, it seems to be necessary to establish appropriate reaction conditions. Hence, they [107] were able to achieve an EMF yield of $65 \%$ at $130{ }^{\circ} \mathrm{C}$ and $0.5 \mathrm{~h}$. The presence of THF as a cosolvent improved this yield up to $76 \%$ in a batch reactor [107] limiting the undesirable formation of humins. H. Wang et al. [108] also used heteropolyacids in the production of EMF from fructose and other polysaccharides achieving an EMF yield of $64 \%$ using DMSO as a cosolvent and phosphotungstic acid (HPW), corroborating the importance of using suitable cosolvents to avoid undesired byproducts. Moreover, they suggest that the existing water in the reaction medium could significantly reduce the EMF yield.

Other authors such as Bing Liu et al. [3] have developed zeolite based new catalysts by immobilizing propyl sulfonic groups on mesoporous silica to build silica-supported sulfonic acids. Using these catalysts and HMF as raw material, different reaction parameters were optimized, concluding that the optimum temperature was $100{ }^{\circ} \mathrm{C}$ for a HMF conversion of $96.5 \%$ and an EMF yield of $83.8 \%$. Moreover, they suggested that: (i) temperatures higher than $100{ }^{\circ} \mathrm{C}$ favor the formation of undesired byproducts derived from HMF polymerization and cross-polymerization [121-123], (ii) high amounts of catalyst derives in the formation of byproducts as ethyl levulinate, (iii) the feed of $\mathrm{C}_{6}$ sugars reduce the EMF yield below $65 \%$ and (iv) catalysts can be reused with no activity loss.

Morales et al. [111] have also used silica sulfate catalysts to obtain EMF from fructose. The EMF yield was $63.4 \%$ at $116{ }^{\circ} \mathrm{C}$ using the $\mathrm{Ar}_{-} \mathrm{SO}_{3} \mathrm{H}-\mathrm{SBA}-15$ catalyst and DMSO as the cosolvent. In this case, the main byproduct was ethyl levulinate. The mentioned catalyst was reused up to four consecutive times, without any regeneration treatment, showing a slight deactivation due to organic deposits on the catalyst surface [111]. 
Finally, another reported incipient heterogeneous catalyst is GO, formed by the Hummers method, based on the exhaustive oxidation from graphite under strong acidic conditions (in concentrated $\mathrm{H}_{2} \mathrm{SO}_{4}$ ) by using permanganate and $\mathrm{H}_{2} \mathrm{O}_{2}$ [112]. After this treatment, the graphene contains numerous oxygen functional groups (alcohols, epoxides and carboxylates) as well as a small quantity of sulfate groups [112]. These functional groups made it possible to achieve a high EMF yield (92\%) from HMF. However, a loose of activity was observed due to the leaching of some active sites limiting its reusability. Different carbohydrate feeds were also tested obtaining EMF yields below 71\% [112].

\section{Conclusions}

This review described the renewable and sustainable catalytic production of value-added biochemical commodities, such as polyols, MAN and AMF from furanic platform molecules, concretely HMF and FF. These biochemicals have many applications in the pharmaceutical and cosmetics industry, in the production of polymers and as biofuels.

With regard to polyols, their formation requires hydrogenation/hydrogenolysis reactions including furan-ring opening. The review of the available literature on this topic indicated that research studies are primarily focused on the synthesis of bifunctional catalysts, composed by noble metal active sites for hydrogenation and acid-basic support for hydrogenolysis, which are tested mainly in batch type reactors. The good performance of these catalysts seems to be related to metallic alloy formation, the Lewis/Brönsted adequate ratio and dispersion of the metal phases. They can be produced in sequential steps and/or using reaction intermediates, and in monophasic and biphasic reaction mediums.

According to MAN, FF oxidation in the gas phase seems to be the most promising alternative in the short term since this feed is one of the few biomass-derived building blocks commercially available currently. However, the oxidation of HMF seems to be a very promising alternative as soon as its commercial production starts increasing. For that purpose, bifunctional catalysts, as in the case of polyols, are the promising ones for the production of this chemical commodity. Concretely, vanadium-containing catalysts, which are currently used in conventional production process of MAN, seem to be good alternatives to carry out the heterogeneous catalytic conversion of HMF into MAN.

As well as in the previous processes, the formulation of a suitable heterogeneous catalyst is essential in the HMF etherification process, being the acid sites the key parameter. It seems that strong Lewis acid favors the EMF yield, comparing with strong Brönsted acid sites. The EMF yield also depends on the operating conditions: temperature, amount of catalyst and cosolvent. The use of a cosolvent could limit or avoid the undesirable byproducts, such as humins.

In the overall, it can be concluded that it is possible to produce different biochemical commodities from FF and HMF. A suitable heterogeneous catalyst formulation is essential in order to enhance the selectivity toward the target products and get stable catalytic systems. For this purpose a deeper characterization of the catalysts and the used of continuous reaction systems or catalyst reusability tests in batch systems are necessary. Thus, a deeper correlation among activity, selectivity and characterization would lead to discover the reaction mechanism, especially in the case of MAN and AMF.

Author Contributions: A.I. was in charge of Section 2 (Polyols); I.A. was in charge of Section 3 (MAN) while N.V. was in charge of the Introduction section. Finally, J.R. was in charge of Section 4 (AMF). All authors discussed the results/information and contributed to the final manuscript. All authors have read and agreed to the published version of the manuscript.

Funding: This work was supported by funds from University of the Basque Country (UPV/EHU), Spanish Ministry of Economy and Innovation (Projects: RTI2018-094918-B-C43), and Basque Country Government (Project: IT993-16).

Conflicts of Interest: The authors declare no conflict of interest. 


\section{Abbreviations}

\begin{tabular}{ll} 
1,2-HD & 1,2-hexanediol \\
1,2-PD & 1,2-pentanediol \\
1,2,5-HT & 1,2,5-hexanetriol \\
1,2,5-PT & 1,2,5-pentanetriol \\
1,4-PD & 1,4-pentanediol \\
1,5-HD & 1,5-hexanediol \\
1,5-PD & 1,5-pentanediol \\
2-MF & 2-methylfuran \\
2-MTHF & 2-methyltetrahydrofuran \\
AMF & alkoxymethylfurfural \\
DDMF & 5-dodecyloxymethylfurfural \\
DFF & 2,5-diformylfuran \\
DHMF & 2,5-dihydroxymethylfuran \\
DHMTHF & 2,5-dihydroxymethyltetrahydrofuran \\
DMSO & dimethyl sulfoxide \\
EMF & 5-ethoxymethylfurfural \\
FDCA & 2,5-furandicarboxylic acid \\
FF & furfural \\
FFA & furfuryl alcohol \\
FFCA & 5-formyl-2-furancarboxylic acid \\
FMF & [(formate)methyl]furfural \\
GO & Graphene oxide \\
GVL & $\gamma$-valerolactone \\
HD & 1,6-hexanediol \\
HDMF & 5-hexadecyloxymethylfurfural \\
HMF & 5-hydroxymethylfurfural \\
HMFCA & 5-hydroxymethyl-2-furancarboxylic acid \\
HT & 1,2,6-hexanetriol \\
IPMF & 5-isopropoxymethylfurfural \\
MAN & maleic anhydride \\
MIBK & methyl isobutyl ketone \\
MMF & methoximethylfurfural \\
OBMF & 5,5-oxybismethylene-2-furaldehyde \\
OMF & 5-octyloxymethylfurfural \\
TBMF & 5-tert-butoxymethylfurfural \\
THF & tetrahydrofuran \\
THFA & tetrahydrofurfuryl alcohol \\
THFF & tetrahydrofurfural \\
V-GO & graphene oxide supported vanadium catalyst \\
& \\
\hline
\end{tabular}

\section{References}

1. BP. BP Statistical Review of World Energy, 68th ed.; BP: London, UK, 2019.

2. Mariscal, R.; Maireles-Torres, P.; Ojeda, M.; Sádaba, I.; López Granados, M. Furfural: A renewable and versatile platform molecule for the synthesis of chemicals and fuels. Energy Environ. Sci. 2016, 9, 1144-1189. [CrossRef]

3. Liu, B.; Zhang, Z. One-pot conversion of carbohydrates into 5-ethoxymethylfurfural and ethyl d-glucopyranoside in ethanol catalyzed by a silica supported sulfonic acid catalyst. RSC Adv. 2013, 3, 12313-12319. [CrossRef]

4. U.S. Energy Information Administration. International Energy Outlook 2017; IEO2017; U.S. Energy Information Administration: Washington, DC, USA, 2017; p. 143.

5. Luo, Y.; Li, Z.; Li, X.; Liu, X.; Fan, J.; Clark, J.H.; Hu, C. The production of furfural directly from hemicellulose in lignocellulosic biomass: A review. Catal. Today 2019, 319, 14-24. [CrossRef] 
6. Cai, C.M.; Zhang, T.; Kumar, R.; Wyman, C.E. Integrated furfural production as a renewable fuel and chemical platform from lignocellulosic biomass. J. Chem. Technol. Biotechnol. 2014, 89, 2-10. [CrossRef]

7. Naidu, D.S.; Hlangothi, S.P.; John, M.J. Bio-based products from xylan: A review. Carbohydr. Polym. 2018, 179, 28-41. [CrossRef]

8. Peleteiro, S.; Rivas, S.; Alonso, J.L.; Santos, V.; Parajó, J.C. Furfural production using ionic liquids: A review. Bioresour. Technol. 2016, 202, 181-191. [CrossRef]

9. Sella Kapu, N.; Trajano, H.L. Review of hemicellulose hydrolysis in softwoods and bamboo. Biofuels Bioprod. Biorefin. 2014, 8, 857-870. [CrossRef]

10. Zhang, L.; Xi, G.; Chen, Z.; Qi, Z.; Wang, X. Enhanced formation of 5-HMF from glucose using a highly selective and stable SAPO-34 catalyst. Chem. Eng. J. 2017, 307, 877-883. [CrossRef]

11. Zhang, Y.; Zhang, J.; Su, D. 5-Hydroxymethylfurfural: A key intermediate for efficient biomass conversion. J. Energy Chem. 2015, 24, 548-551. [CrossRef]

12. Yan, K.; Wu, G.; Lafleur, T.; Jarvis, C. Production, properties and catalytic hydrogenation of furfural to fuel additives and value-added chemicals. Renew. Sustain. Energy Rev. 2014, 38, 663-676. [CrossRef]

13. Bozell, J.J.; Petersen, G.R. Technology development for the production of biobased products from biorefinery carbohydrates-The US Department of Energy's “top 10" revisited. Green Chem. 2010, 12, 539-554. [CrossRef]

14. Nhien, L.C.; Long, N.V.D.; Kim, S.; Lee, M. Design and optimization of intensified biorefinery process for furfural production through a systematic procedure. Biochem. Eng. J. 2016, 116, 166-175. [CrossRef]

15. Chheda, J.N.; Roman-Leshkov, Y.; Dumesic, J.A. Production of 5-hydroxymethylfurfural and furfural by dehydration of biomass-derived mono- and poly-saccharides. Green Chem. 2007, 9, 342-350. [CrossRef]

16. Requies, J.; Agirre, I.; Iriondo, A. Production of Furanic Biofuels with Zeolite and Metal Oxide Bifunctional Catalysts for Energy- and Product-Driven Biorefineries. In Production of Biofuels and Chemicals with Bifunctional Catalysts; Fang, Z., Richard, L.S., Jr., Li, H., Eds.; Springer: Singapore, 2017; p. 504. ISBN 978-981-10-5136-4.

17. Agirrezabal-Telleria, I.; Gandarias, I.; Arias, P.L. Heterogeneous acid-catalysts for the production of furan-derived compounds (furfural and hydroxymethylfurfural) from renewable carbohydrates: A review. Catal. Today 2014, 234, 42-58. [CrossRef]

18. Teong, S.P.; Yi, G.; Zhang, Y. Hydroxymethylfurfural production from bioresources: Past, present and future. Green Chem. 2014, 16, 2015-2026. [CrossRef]

19. Van Nguyen, C.; Lewis, D.; Chen, W.H.; Huang, H.W.; ALOthman, Z.A.; Yamauchi, Y.; Wu, K.C.W. Combined treatments for producing 5-hydroxymethylfurfural (HMF) from lignocellulosic biomass. Catal. Today 2016, 278, 344-349. [CrossRef]

20. Yu, I.K.M.; Tsang, D.C.W. Conversion of biomass to hydroxymethylfurfural: A review of catalytic systems and underlying mechanisms. Bioresour. Technol. 2017, 238, 716-732. [CrossRef]

21. Kong, Q.S.; Li, X.L.; Xu, H.J.; Fu, Y. Conversion of 5-hydroxymethylfurfural to chemicals: A review of catalytic routes and product applications. Fuel Process. Technol. 2020, 209, 106528. [CrossRef]

22. Wang, C.; Zhang, X.; Liu, Q.; Zhang, Q.; Chen, L.; Ma, L. A review of conversion of lignocellulose biomass to liquid transport fuels by integrated refining strategies. Fuel Process. Technol. 2020, 208, 106485. [CrossRef]

23. Hu, L.; Lin, L.; Wu, Z.; Zhou, S.; Liu, S. Recent advances in catalytic transformation of biomass-derived 5-hydroxymethylfurfural into the innovative fuels and chemicals. Renew. Sustain. Energy Rev. 2017, 74, 230-257. [CrossRef]

24. Tang, X.; Wei, J.; Ding, N.; Sun, Y.; Zeng, X.; Hu, L.; Liu, S.; Lei, T.; Lin, L. Chemoselective hydrogenation of biomass derived 5-hydroxymethylfurfural to diols: Key intermediates for sustainable chemicals, materials and fuels. Renew. Sustain. Energy Rev. 2017, 77, 287-296. [CrossRef]

25. Nakagawa, Y.; Tamura, M.; Tomishige, K. Supported metal catalysts for total hydrogenation of furfural and 5-hydroxymethylfurfural. J. Jpn. Pet. Inst. 2017, 60, 1-9. [CrossRef]

26. Buntara, T.; Melián-Cabrera, I.; Tan, Q.; Fierro, J.L.G.; Neurock, M.; De Vries, J.G.; Heeres, H.J. Catalyst studies on the ring opening of tetrahydrofuran-dimethanol to 1,2,6-hexanetriol. Catal. Today 2013, 210, 106-116. [CrossRef]

27. Yao, S.; Wang, X.; Jiang, Y.; Wu, F.; Chen, X.; Mu, X. One-step conversion of biomass-derived 5-hydroxymethylfurfural to 1,2,6-hexanetriol over ni-co-al mixed oxide catalysts under mild conditions. ACS Sustain. Chem. Eng. 2014, 2, 173-180. [CrossRef]

28. Lohbeck, K.; Haferkorn, H.; Fuhrmann, W.; Fedtke, N. Maleic and Fumaric Acids; Ullmann's Encyclopedia of Industrial Chemistry (Wiley): Hoboken, NJ, USA, 2000. [CrossRef] 
29. Resins, L.; Felthouse, T.R.; Burnett, J.C.; Horrell, B.; Mummey, M.J.; Kuo, Y.-J. Maleic Anhydride, Maleic Acid, and Fumaric Acid. Kirk-Othmer Encycl. Chem. Technol. 2001, 1-49. [CrossRef]

30. Bridgwater, A.; Chinthapalli, R.; Smith, P. Identification and Market Analysis of Most Promising Added-Value Products to Be Co-Produced with the Fuels; Biored-Integ European Proyect, Aston University: Birmingham, UK, 2010.

31. Alonso-Fagúndez, N.; Ojeda, M.; Mariscal, R.; Fierro, J.L.G.L.G.; López Granados, M. Gas phase oxidation of furfural to maleic anhydride on $\mathrm{V}_{2} \mathrm{O}_{5} / \Gamma-\mathrm{Al}_{2} \mathrm{O}_{3}$ catalysts: Reaction conditions to slow down the deactivation. J. Catal. 2017, 348, 265-275. [CrossRef]

32. Ghaznavi, T.; Neagoe, C.; Patience, G.S. Partial oxidation of d-xylose to maleic anhydride and acrylic acid over vanadyl pyrophosphate. Biomass Bioenergy 2014, 71, 285-293. [CrossRef]

33. Du, Z.; Ma, J.; Wang, F.; Liu, J.; Xu, J. Oxidation of 5-hydroxymethylfurfural to maleic anhydride with molecular oxygen. Green Chem. 2011, 13, 554-557. [CrossRef]

34. Liu, H.; Tang, X.; Hao, W.; Zeng, X.; Sun, Y.; Lei, T.; Lin, L. One-pot tandem conversion of fructose into biofuel components with in-situ generated catalyst system. J. Energy Chem. 2018, 27, 375-380. [CrossRef]

35. Yang, Y.; Hu, C.; Abu-Omar, M.M. Conversion of glucose into furans in the presence of $\mathrm{AlCl} 3$ in an ethanol-water solvent system. Bioresour. Technol. 2012, 116, 190-194. [CrossRef]

36. Thombal, R.S.; Jadhav, V.H. Application of glucose derived magnetic solid acid for etherification of 5-HMF to 5-EMF, dehydration of sorbitol to isosorbide, and esterification of fatty acids. Tetrahedron Lett. 2016, 57, 4398-4400. [CrossRef]

37. Gupta, D.; Saha, B. Dual acidic titania carbocatalyst for cascade reaction of sugar to etherified fuel additives. Catal. Commun. 2018, 110, 46-50. [CrossRef]

38. Moreau, C.; Belgacem, M.N.N.; Gandini, A. Recent catalytic advances in the chemistry of substituted furans from carbohydrates and in the ensuing polymers. Top. Catal. 2004, 27, 11-30. [CrossRef]

39. Climent, M.J.J.J.; Corma, A.; Iborra, S. Conversion of biomass platform molecules into fuel additives and liquid hydrocarbon fuels. Green Chem. 2014, 16, 516-547. [CrossRef]

40. Triebl, C.; Nikolakis, V.; Ierapetritou, M. Simulation and economic analysis of 5-hydroxymethylfurfural conversion to 2,5-furandicarboxylic acid. Comput. Chem. Eng. 2013, 52, 26-34. [CrossRef]

41. He, J.; Burt, S.P.; Ball, M.; Zhao, D.; Hermans, I.; Dumesic, J.A.; Huber, G.W. Synthesis of 1,6-Hexanediol from Cellulose Derived Tetrahydrofuran-Dimethanol with Pt-WOx/TiO2Catalysts. ACS Catal. 2018, 8, 1427-1439. [CrossRef]

42. Alamillo, R.; Tucker, M.; Chia, M.; Pagán-Torres, Y.; Dumesic, J. The selective hydrogenation of biomass-derived 5-hydroxymethylfurfural using heterogeneous catalysts. Green Chem. 2012, 14, 1413-1419. [CrossRef]

43. Li, N.; Huber, G.W. Aqueous-phase hydrodeoxygenation of sorbitol with $\mathrm{Pt} / \mathrm{SiO}_{2}-\mathrm{Al}_{2} \mathrm{O}_{3}$ : Identification of reaction intermediates. J. Catal. 2010, 270, 48-59. [CrossRef]

44. Buntara, T.; Noel, S.; Phua, P.H.; Melián-Cabrera, I.; De Vries, J.G.; Heeres, H.J. Caprolactam from renewable resources: Catalytic conversion of 5-hydroxymethylfurfural into caprolactone. Angew. Chem. Int. Ed. 2011, 50, 7083-7087. [CrossRef]

45. Xiao, B.; Zheng, M.; Li, X.; Pang, J.; Sun, R.; Wang, H.; Pang, X.; Wang, A.; Wang, X.; Zhang, T. Synthesis of 1,6-hexanediol from HMF over double-layered catalysts of $\mathrm{Pd} / \mathrm{SiO}_{2}+\mathrm{Ir}-\mathrm{ReOx} / \mathrm{SiO}_{2}$ in a fixed-bed reactor. Green Chem. 2016, 18, 2175-2184. [CrossRef]

46. Iriondo, A.; Mendiguren, A.; Güemez, M.B.; Requies, J.; Cambra, J.F. 2,5-DMF production through hydrogenation of real and synthetic 5-HMF over transition metal catalysts supported on carriers with different nature. Catal. Today 2017, 279, 286-295. [CrossRef]

47. Vilcocq, L.; Cabiac, A.; Especel, C.; Lacombe, S.; Duprez, D. New insights into the mechanism of Sorbitol transformation over an original bifunctional catalytic system. J. Catal. 2014, 320, 16-25. [CrossRef]

48. Ohyama, J.; Satsuma, A. Reductive Conversion of 5-Hydroxymethylfurfural in Aqueous Solutions by Furan Ring Opening and Rearrangement. In Production of Biofuels and Chemicals with Bifunctional Catalysts; Fang, Z., Richard, L.S., Jr., Li, H., Eds.; Springer: Singapore, 2017; pp. 159-185. ISBN 9789811051371.

49. Chen, J.; Ge, Y.; Guo, Y.; Chen, J. Selective hydrogenation of biomass-derived 5-hydroxymethylfurfural using palladium catalyst supported on mesoporous graphitic carbon nitride. J. Energy Chem. 2018, 27, 283-289. [CrossRef] 
50. He, J.; Burt, S.P.; Ball, M.R.; Hermans, I.; Dumesic, J.A.; Huber, G.W. Catalytic C-O bond hydrogenolysis of tetrahydrofuran-dimethanol over metal supported $\mathrm{WOx} / \mathrm{TiO}_{2}$ catalysts. Appl. Catal. B Environ. 2019, 258, 117945. [CrossRef]

51. Liu, F.; Audemar, M.; De Oliveira Vigier, K.; Clacens, J.M.; De Campo, F.; Jérôme, F. Palladium/carbon dioxide cooperative catalysis for the production of diketone derivatives from carbohydrates. ChemSusChem 2014, 7, 2089-2093. [CrossRef]

52. Kataoka,H.; Kosuge, D.; Ogura, K.; Ohyama, J.; Satsuma, A. Reductive conversion of 5-hydroxymethylfurfural to 1,2,6-hexanetriol in water solvent using supported Pt catalysts. Catal. Today 2020, 352, 60-65. [CrossRef]

53. Wang, Y.; Zhu, W.; Sang, S.; Gao, L.; Xiao, G. Supported Cu catalysts for the hydrogenation of furfural in aqueous phase: Effect of support. Asia-Pac. J. Chem. Eng. 2017, 12, 422-431. [CrossRef]

54. Nakagawa, Y.; Tamura, M.; Tomishige, K. Catalytic Conversions of Furfural to Pentanediols. Catal. Surv. Asia 2015, 19, 249-256. [CrossRef]

55. Tuteja, J.; Choudhary, H.; Nishimura, S.; Ebitani, K. Direct synthesis of 1,6-hexanediol from HMF over a heterogeneous $\mathrm{Pd} / \mathrm{ZrP}$ catalyst using formic acid as hydrogen source. ChemSusChem 2014, 7, 96-100. [CrossRef]

56. Nakagawa, Y.; Mori, K.; Chen, K.; Amada, Y.; Tamura, M.; Tomishige, K. Hydrogenolysis of CO bond over Re-modified Ir catalyst in alkane solvent. Appl. Catal. A Gen. 2013, 468, 418-425. [CrossRef]

57. Buntara, T.; Noel, S.; Phua, P.H.; Melián-Cabrera, I.; De Vries, J.G.; Heeres, H.J. From 5-hydroxymethylfurfural (HMF) to polymer precursors: Catalyst screening studies on the conversion of 1,2,6-hexanetriol to 1,6-hexanediol. Top. Catal. 2012, 55, 612-619. [CrossRef]

58. Liu, S.; Amada, Y.; Tamura, M.; Nakagawa, Y.; Tomishige, K. Performance and characterization of rhenium-modified Rh-Ir alloy catalyst for one-pot conversion of furfural into 1,5-pentanediol. Catal. Sci. Technol. 2014, 4, 2535-2549. [CrossRef]

59. Liu, H.; Huang, Z.; Kang, H.; Xia, C.; Chen, J. Selective hydrogenolysis of biomass-derived furfuryl alcohol into 1,2- and 1,5-pentanediol over highly dispersed $\mathrm{Cu}-\mathrm{Al}_{2} \mathrm{O}_{3}$ catalysts. Cuihua Xuebao/Chin. J. Catal. 2016, 37, 700-710. [CrossRef]

60. Musci, J.J.; Merlo, A.B.; Casella, M.L. Aqueous phase hydrogenation of furfural using carbon-supported Ru and RuSn catalysts. Catal. Today 2017, 296, 43-50. [CrossRef]

61. Xu, W.; Wang, H.; Liu, X.; Ren, J.; Wang, Y.; Lu, G. Direct catalytic conversion of furfural to 1,5-pentanediol by hydrogenolysis of the furan ring under mild conditions over $\mathrm{Pt} / \mathrm{Co}_{2} \mathrm{AlO}_{4}$ catalyst. Chem. Commun. 2011, 47, 3924-3926. [CrossRef]

62. Date, N.S.; Chikate, R.C.; Roh, H.S.; Rode, C.V. Bifunctional role of Pd/MMT-K 10 catalyst in direct transformation of furfural to 1,2-pentanediol. Catal. Today 2017, 309, 195-201. [CrossRef]

63. Soghrati, E.; Choong, C.; Poh, C.K.; Kawi, S.; Borgna, A. Single-Pot Conversion of Tetrahydrofurfuryl Alcohol into Tetrahydropyran over a Ni/HZSM-5 Catalyst under Aqueous-Phase Conditions. ChemCatChem 2017, 9 , 1402-1408. [CrossRef]

64. Liu, S.; Amada, Y.; Tamura, M.; Nakagawa, Y.; Tomishige, K. One-pot selective conversion of furfural into 1,5-pentanediol over a Pd-added Ir-ReOx/SiO 2 bifunctional catalyst. Green Chem. 2014, 16, 617-626. [CrossRef]

65. Mizugaki, T.; Yamakawa, T.; Nagatsu, Y.; Maeno, Z.; Mitsudome, T.; Jitsukawa, K.; Kaneda, K. Direct transformation of furfural to 1,2-pentanediol using a hydrotalcite-supported platinum nanoparticle catalyst. ACS Sustain. Chem. Eng. 2014, 2, 2243-2247. [CrossRef]

66. Yeh, J.; Matsagar, B.M.; Chen, S.S.; Sung, H.; Tsang, D.C.W.; Li, Y.; Wu, K.C. Synergistic Effects of Pt-embedded, MIL-53-derived Pentanediol at Near-ambient Temperature. J. Catal. 2020. [CrossRef]

67. Pisal, D.S.; Yadav, G.D. Single-Step Hydrogenolysis of Furfural to 1,2-Pentanediol Using a Bifunctional Rh/OMS-2 Catalyst. ACS Omega 2019, 4, 1201-1214. [CrossRef] [PubMed]

68. Wang, N.; Chen, Z.; Liu, L. Acid catalysis dominated suppression of xylose hydrogenation with increasing yield of 1,2-pentanediol in the acid-metal dual catalyst system. Appl. Catal. A Gen. 2018, 561, 41-48. [CrossRef]

69. Pavarelli, G.; Velasquez Ochoa, J.; Caldarelli, A.; Puzzo, F.; Cavani, F.; Dubois, J.L. A New Process for Maleic Anhydride Synthesis from a Renewable Building Block: The Gas-Phase Oxidehydration of Bio-1-butanol. ChemSusChem 2015, 8, 2250-2259. [CrossRef] [PubMed] 
70. Chatzidimitriou, A.; Bond, J.Q. Oxidation of levulinic acid for the production of maleic anhydride: Breathing new life into biochemicals. Green Chem. 2015, 17, 4367-4376. [CrossRef]

71. Lan, J.; Lin, J.; Chen, Z.; Yin, G. Transformation of 5-Hydroxymethylfurfural (HMF) to Maleic Anhydride by Aerobic Oxidation with Heteropolyacid Catalysts. ACS Catal. 2015, 5, 2035-2041. [CrossRef]

72. Lv, G.; Chen, C.; Lu, B.; Li, J.; Yang, Y.; Chen, C.; Deng, T.; Zhu, Y.; Hou, X. Vanadium-oxo immobilized onto Schiff base modified graphene oxide for efficient catalytic oxidation of 5-hydroxymethylfurfural and furfural into maleic anhydride. RSC Adv. 2016, 6, 101277-101282. [CrossRef]

73. Alonso-Fagúndez, N.; Laserna, V.; Alba-Rubio, A.C.; Mengibar, M.; Heras, A.; Mariscal, R.; Granados, M.L. Poly-(styrene sulphonic acid): An acid catalyst from polystyrene waste for reactions of interest in biomass valorization. Catal. Today 2014, 234, 285-294. [CrossRef]

74. Alonso-Fagúndez, N.; Agirrezabal-Telleria, I.; Arias, P.L.; Fierro, J.L.G.; Mariscal, R.; Granados, M.L. Aqueous-phase catalytic oxidation of furfural with $\mathrm{H}_{2} \mathrm{O}_{2}$ : High yield of maleic acid by using titanium silicalite-1. RSC Adv. 2014, 4, 54960-54972. [CrossRef]

75. Alba-Rubio, A.C.; Fierro, J.L.G.; León-Reina, L.; Mariscal, R.; Dumesic, J.A.; López Granados, M. Oxidation of furfural in aqueous $\mathrm{H} 2 \mathrm{O} 2$ catalysed by titanium silicalite: Deactivation processes and role of extraframework Ti oxides. Appl. Catal. B Environ. 2017, 202, 269-280. [CrossRef]

76. Lan, J.; Chen, Z.; Lin, J.; Yin, G. Catalytic aerobic oxidation of renewable furfural to maleic anhydride and furanone derivatives with their mechanistic studies. Green Chem. 2014, 16, 4351-4358. [CrossRef]

77. Choudhary, H.; Nishimura, S.; Ebitani, K. Metal-free oxidative synthesis of succinic acid from biomass-derived furan compounds using a solid acid catalyst with hydrogen peroxide. Appl. Catal. A Gen. 2013, 458, 55-62. [CrossRef]

78. Hemant, C.; Shun, N.; Kohki, E. Highly Efficient Aqueous Oxidation of Furfural to Succinic Acid Using Reusable Heterogeneous Acid Catalyst with Hydrogen Peroxide. Chem. Lett. 2012, 41, 409-411.

79. Li, X.; Lan, X.; Wang, T. Selective oxidation of furfural in a bi-phasic system with homogeneous acid catalyst. Catal. Today 2016, 276, 97-104. [CrossRef]

80. Huang, Y.; Wu, C.; Yuan, W.; Xia, Y.; Liu, X.; Yang, H.; Wang, H. Catalytic Aerobic Oxidation of Biomass-based Furfural into Maleic Acid in Aqueous Phase with Metalloporphyrin Catalysts. J. Chin. Chem. Soc. 2017, 64, 786-794. [CrossRef]

81. Shi, S.; Guo, H.; Yin, G. Synthesis of maleic acid from renewable resources: Catalytic oxidation of furfural in liquid media with dioxygen. Catal. Commun. 2011, 12, 731-733. [CrossRef]

82. Gabriele, C.; van Santen, R.A. Conclusions, Perspectives and Roadmap. In Catalysis for Renewables; Wiley-Blackwell: Weinheim, Germany, 2007; pp. 387-411. ISBN 9783527621118.

83. Li, X.; Zhang, Y. The conversion of 5-hydroxymethyl furfural (HMF) to maleic anhydride with vanadium-based heterogeneous catalysts. Green Chem. 2016, 18, 643-647. [CrossRef]

84. Lv, G.; Deng, L.; Lu, B.; Li, J.; Hou, X.; Yang, Y. Efficient dehydration of fructose into 5-hydroxymethylfurfural in aqueous medium over silica-included heteropolyacids. J. Clean. Prod. 2017, 142, 2244-2251. [CrossRef]

85. Chai, L.; Hou, X.; Cui, X.; Li, H.; Zhang, N.; Zhang, H.; Chen, C.; Wang, Y.; Deng, T. 5-Hydroxymethylfurfural oxidation to Maleic acid by $\mathrm{O}_{2}$ over graphene oxide supported vanadium: Solvent effects and reaction mechanism. Chem. Eng. J. 2020, 388, 124187. [CrossRef]

86. Jia, W.; Si, Z.; Feng, Y.; Zhang, X.; Zhao, X.; Sun, Y.; Sun, Y.; Sun, Y.; Tang, X.; Zeng, X.; et al. Oxidation of 5-[(Formyloxy)methyl]-furfural to Maleic Anhydride with Atmospheric Oxygen Using $\alpha-\mathrm{MnO} 2 / \mathrm{Cu}(\mathrm{NO} 3) 2$ as Catalysts. ACS Sustain. Chem. Eng. 2020, 8, 7901-7908. [CrossRef]

87. Guo, H.; Yin, G. Catalytic aerobic oxidation of renewable furfural with phosphomolybdic acid catalyst: An alternative route to maleic acid. J. Phys. Chem. C 2011, 115, 17516-17522. [CrossRef]

88. Soták, T.; Hronec, M.; Gál, M.; Dobročka, E.; Škriniarová, J. Aqueous-Phase Oxidation of Furfural to Maleic Acid Catalyzed by Copper Phosphate Catalysts. Catal. Lett. 2017, 147, 2714-2723. [CrossRef]

89. Alonso-Fagúndez, N.; Granados, M.L.; Mariscal, R.; Ojeda, M. Selective conversion of furfural to maleic anhydride and furan with $\mathrm{VOx} / \mathrm{Al}_{2} \mathrm{O}_{3}$ catalysts. ChemSusChem 2012, 5, 1984-1990. [CrossRef] [PubMed]

90. Santander, P.; Bravo, L.; Pecchi, G.; Karelovic, A. The consequences of support identity on the oxidative conversion of furfural to maleic anhydride on vanadia catalysts. Appl. Catal. A Gen. 2020, 595, 117513. [CrossRef] 
91. Araji, N.; Madjinza, D.D.; Chatel, G.; Moores, A.; Jérôme, F.; De Oliveira Vigier, K. Synthesis of maleic and fumaric acids from furfural in the presence of betaine hydrochloride and hydrogen peroxide. Green Chem. 2017, 19, 98-101. [CrossRef]

92. Saleem, F.; Müller, P.; Eränen, K.; Warnå, J.; Yu Murzin, D.; Salmi, T. Kinetics and modelling of furfural oxidation with hydrogen peroxide over a fibrous heterogeneous catalyst: Effect of reaction parameters on yields of succinic acid. J. Chem. Technol. Biotechnol. 2017, 92, 2206-2220. [CrossRef]

93. Agirre, I.; Gandarias, I.; Granados, M.L.; Arias, P.L. Process design and techno-economic analysis of gas and aqueous phase maleic anhydride production from biomass-derived furfural. Biomass Convers. Biorefin. 2019. [CrossRef]

94. Milas, N.A.; Walsh, W.L. Catalytic Oxidations. I. Oxidations in the Furan Series. J. Am. Chem. Soc. 1935, 57, 1389-1393. [CrossRef]

95. Rajamani, K.; Subramanian, P.; Murthy, M.S. Kinetics and Mechanism of Vapor Phase Oxidation of Furfural over Tin Vanadate Catalyst. Ind. Eng. Chem. Process Des. Dev. 1976, 15, 232-234. [CrossRef]

96. Kläusli, T. AVA Biochem: Commercialising renewable platform chemical 5-HMF. Green Process. Synth. 2014, 3, 235-236. [CrossRef]

97. Yang, F.; Zhang, S.; Zhang, Z.C.; Mao, J.; Li, S.; Yin, J.; Zhou, J. A biodiesel additive: Etherification of 5-hydroxymethylfurfural with isobutene to tert-butoxymethylfurfural. Catal. Sci. Technol. 2015, 5, 4602-4612. [CrossRef]

98. Sarin, R.; Kumar, R.; Srivastav, B.; Puri, S.K.; Tuli, D.K.; Malhotra, R.K.; Kumar, A. Biodiesel surrogates: Achieving performance demands. Bioresour. Technol. 2009, 100, 3022-3028. [CrossRef] [PubMed]

99. Chen, T.; Peng, L.; Yu, X.; He, L. Magnetically recyclable cellulose-derived carbonaceous solid acid catalyzed the biofuel 5-ethoxymethylfurfural synthesis from renewable carbohydrates. Fuel 2018, 219, 344-352. [CrossRef]

100. Balakrishnan, M.; Sacia, E.R.; Bell, A.T. Etherification and reductive etherification of 5-(hydroxymethyl)furfural: 5-(alkoxymethyl)furfurals and 2,5-bis(alkoxymethyl)furans as potential bio-diesel candidates. Green Chem. 2012, 14, 1626-1634. [CrossRef]

101. Lai, L.; Zhang, Y. The production of 5-hydroxymethylfurfural from fructose in isopropyl alcohol: A green and efficient system. ChemSusChem 2011, 4, 1745-1748. [CrossRef]

102. Liu, B.; Zhang, Z.; Huang, K.; Fang, Z. Efficient conversion of carbohydrates into 5-ethoxymethylfurfural in ethanol catalyzed by $\mathrm{AlCl}_{3}$. Fuel 2013, 113, 625-631. [CrossRef]

103. Zhou, X.; Zhang, Z.; Liu, B.; Zhou, Q.; Wang, S.; Deng, K. Catalytic conversion of fructose into furans using $\mathrm{FeCl}_{3}$ as catalyst. J. Ind. Eng. Chem. 2014, 20, 644-649. [CrossRef]

104. Pereira, J.G.; Sousa, S.C.A.; Fernandes, A.C. Direct Conversion of Carbohydrates into 5-Ethoxymethylfurfural (EMF) and 5-Hydroxymethylfurfural (HMF) catalyzed by Oxomolybdenum complexes. ChemistrySelect 2017, 2, 4516-4521. [CrossRef]

105. Guo, H.; Qi, X.; Hiraga, Y.; Aida, T.M.; Smith, R.L. Efficient conversion of fructose into 5-ethoxymethylfurfural with hydrogen sulfate ionic liquids as co-solvent and catalyst. Chem. Eng. J. 2017, 314, 508-514. [CrossRef]

106. Guo, H.; Duereh, A.; Hiraga, Y.; Aida, T.M.; Qi, X.; Smith, R.L. Perfect recycle and mechanistic role of hydrogen sulfate ionic liquids as additive in ethanol for efficient conversion of carbohydrates into 5-ethoxymethylfurfural. Chem. Eng. J. 2017, 323, 287-294. [CrossRef]

107. Yang, Y.; Abu-Omar, M.M.; Hu, C. Heteropolyacid catalyzed conversion of fructose, sucrose, and inulin to 5-ethoxymethylfurfural, a liquid biofuel candidate. Appl. Energy 2012, 99, 80-84. [CrossRef]

108. Wang, H.; Deng, T.; Wang, Y.; Qi, Y.; Hou, X.; Zhu, Y. Efficient catalytic system for the conversion of fructose into 5-ethoxymethylfurfural. Bioresour. Technol. 2013, 136, 394-400. [CrossRef] [PubMed]

109. Liu, A.; Liu, B.; Wang, Y.; Ren, R.; Zhang, Z. Efficient one-pot synthesis of 5-ethoxymethylfurfural from fructose catalyzed by heteropolyacid supported on K-10 clay. Fuel 2014, 117, 68-73. [CrossRef]

110. Li, H.; Govind, K.S.; Kotni, R.; Shunmugavel, S.; Riisager, A.; Yang, S. Direct catalytic transformation of carbohydrates into 5-ethoxymethylfurfural with acid-base bifunctional hybrid nanospheres. Energy Convers. Manag. 2014, 88, 1245-1251. [CrossRef]

111. Morales, G.; Paniagua, M.; Melero, J.A.; Iglesias, J. Efficient production of 5-ethoxymethylfurfural from fructose by sulfonic mesostructured silica using DMSO as co-solvent. Catal. Today 2017, 279, 305-316. [CrossRef] 
112. Wang, H.; Deng, T.; Wang, Y.; Cui, X.; Qi, Y.; Mu, X.; Hou, X.; Zhu, Y. Graphene oxide as a facile acid catalyst for the one-pot conversion of carbohydrates into 5-ethoxymethylfurfural. Green Chem. 2013, 15, 2379-2383. [CrossRef]

113. Collignon, F.; Loenders, R.; Martens, J.A.; Jacobs, P.A.; Poncelet, G. Liquid phase synthesis of MTBE from methanol and isobutene over acid zeolites and amberlyst-15. J. Catal. 1999, 182, 302-312. [CrossRef]

114. Guzmán, I.; Heras, A.; Güemez, M.B.; Iriondo, A.; Cambra, J.F.; Requies, J. Levulinic Acid Production Using Solid-Acid Catalysis. Ind. Eng. Chem. Res. 2016, 55, 5139-5144. [CrossRef]

115. Lanzafame, P.; Temi, D.M.; Perathoner, S.; Centi, G.; Macario, A.; Aloise, A.; Giordano, G. Etherification of 5-hydroxymethyl-2-furfural (HMF) with ethanol to biodiesel components using mesoporous solid acidic catalysts. Catal. Today 2011, 175, 435-441. [CrossRef]

116. Fan, C.; Guan, H.; Zhang, H.; Wang, J.; Wang, S.; Wang, X. Conversion of fructose and glucose into 5-hydroxymethylfurfural catalyzed by a solid heteropolyacid salt. Biomass Bioenergy 2011, 35, 2659-2665. [CrossRef]

117. Zhao, Q.; Wang, L.; Zhao, S.; Wang, X.; Wang, S. High selective production of 5-hydroymethylfurfural from fructose by a solid heteropolyacid catalyst. Fuel 2011, 90, 2289-2293. [CrossRef]

118. Cheng, M.; Shi, T.; Wang, S.; Guan, H.; Fan, C.; Wang, X. Fabrication of micellar heteropolyacid catalysts for clean production of monosaccharides from polysaccharides. Catal. Commun. 2011, 12, 1483-1487. [CrossRef]

119. Choi, J.H.; Kim, J.K.; Park, D.R.; Park, S.; Yi, J.; Song, I.K. Etherification of n-butanol to di-n-butyl ether over H3PMo12-XWxO40(x = 0, 3, 6, 9, 12) Keggin and H6P2Mo18-XWxO62(x = 0, 3, 9, 15, 18) Wells-Dawson heteropolyacid catalysts. Catal. Commun. 2011, 14, 48-51. [CrossRef]

120. Kozhevnikov, I.V. Catalysis by heteropoly acids and multicomponent polyoxometalates in liquid-phase reactions. Chem. Rev. 1998, 98, 171-198. [CrossRef] [PubMed]

121. Girisuta, B.; Janssen, L.P.B.M.; Heeres, H.J. A kinetic study on the decomposition of 5-hydroxymethylfurfural into levulinic acid. Green Chem. 2006, 8, 701-709. [CrossRef]

122. Zhang, Z.; Liu, W.; Xie, H.; Zhao, Z.K. An unexpected reaction between 5-hydroxymethylfurfural and imidazolium-based ionic liquids at high temperatures. Molecules 2011, 16, 8463-8474. [CrossRef] [PubMed]

123. Patil, S.K.R.; Lund, C.R.F. Formation and growth of humins via aldol addition and condensation during acid-catalyzed conversion of 5-hydroxymethylfurfural. Energy Fuels 2011, 25, 4745-4755. [CrossRef] 